ROZDZIAŁ 5

\title{
Regulacje organizacyjno-prawne rewitalizacji w wybranych krajach Unii Europejskiej
}

\subsection{Niemcy}

\subsubsection{Mieszkalnictwo i początki odnowy miast}

Niemcy należą do grupy państw, w których rewitalizację rozpoczęto najwcześniej. $Z$ jednej strony zostało to spowodowane ogromem zniszczeń wojennych w miastach i koniecznością odbudowy zburzonych dzielnic, z drugie zaś wysokim stopniem uprzemysłowienia - duża część obiektów przemysłowych została opuszczona i zastąpiona nowocześniejszymi zakładami zbudowanymi na nowych lokalizacjach. Ogromny niedobór mieszkań wobec napływu milionów przesiedleńców z utraconych przez Niemcy terenów wymusił politykę wspierającą szybką i tanią budowę nowych mieszkań, głównie czynszowych, co zaważyło na strukturze własnościowej mieszkań w Niemczech. Do dnia dzisiejszego udział mieszkań prywatnych niewiele przekracza $40 \%$, podczas gdy w Wielkiej Brytanii wynosi on ponad $70 \%{ }^{1}$.

Przyspieszony i żywiołowy program budowy nowych mieszkań (400-540 tys. rocznie $\mathrm{w}$ pocz. lat pięćdziesiątych) spowodował m.in. chaos $\mathrm{w}$ przestrzeni miast i zanik dbałości o stare zasoby. Dodatkowo, podobnie jak w Polsce, przydzielano mieszkania więcej niż jednej rodzinie, co spowodowało tymczasowość zamieszkiwania i w konsekwencji brak dbałości o nie swoją własność.

W końcu lat pięćdziesiątych zaczęto budować osiedla mieszkaniowe wedhug zasad Karty Ateńskiej, stopniowo coraz większe, coraz wyższe i z czasem częściej na peryferiach miast. Wiele osiedli czy niemal całych miast na terenie b. NRD zostało zbudowanych, podobnie jak Nowa Huta, w bezpośrednim sąsiedztwie wielkich zakładów przemysłowych, hut, kopalń i zakładów chemicznych. W latach sześćdziesiątych i siedemdziesiątych budownictwo w NRD zostało zdominowane przez technologię wielkopłytową, a jednocześnie zaniechano niemal zupełnie remontów starych kamienic w centrach miast. W rezultacie stan i wygląd miast pogarszał się: z jednej strony szybko powstawały

${ }^{1}$ M. Bryx, A. Jadach-Sepioło (red.), Rewitalizacja miast $w$ Niemczech, seria: Rewitalizacja Miast Polskich, t. 3, Kraków 2009, s. 18. 
peryferyjne osiedla pozbawione podstawowych często usług, a z drugiej degradacji ulegały stopniowo stare zasoby dzielnic centralnych. Niektóre z nich wyburzano, do innych zakazywano wstępu.

Inne problemy dotknęły miasta na terenie RFN. Szybki rozwój gospodarki, będący skutkiem proinwestycyjnej polityki kolejnych rządów ${ }^{2}$ i Planu Marshala, spowodował napływ imigrantów-gastarbaiterów. Zajmowali oni na ogół mieszkania $\mathrm{w}$ centralnych częściach miast, opuszczanych przez bogatszych mieszkańców przenoszących się do strefy podmiejskiej. Przyspieszyło to procesy suburbanizacji spotęgowanej przez szybki rozwój przemysłu na obrzeżach miast. W centrach pozostawali ludzie na ogół starsi, często samotni. $\mathrm{W}$ połowie lat sześćdziesiątych podjęto próby uporządkowania rozwoju miast, okres ten można także uznać za początek myślenia w kategoriach odnowy miast i rozpoczęcia procesów rewitalizacji ${ }^{3}$. Dotychczasowe próby poprawy standardów zabudowy polegały głównie na rozbiórkach i budowaniu na miejscu zburzonych budynków nowych obiektów zgodnie z ówczesnymi wymogami. Powodowało to jednak często naruszenie starej, często zabytkowej substancji mieszkaniowej w imię nowoczesności, budziło opór konserwatorów zabytków i sprzeciw społeczny. Jednym ze sposobów walki z masowymi wyburzeniami było nielegalne zajmowanie przez okolicznych mieszkańców budynków przeznaczanych do rozbiórki (tzw. Hausbesetzer - odpowiednik angielskich squattersów). Zaczęto w końcu dostrzegać rolę starej, historycznej zabudowy w kształtowaniu indywidualnego charakteru miast, coraz bardziej liczono się ze zdaniem konserwatorów zabytków.

Cały niemal zakres prac i kosztów związanych z ówczesną odnową miast finansowany był $\mathrm{z}$ budżetu federalnego, co spowodowało kryzys finansów publicznych i modyfikację systemu finansowania.

Wykorzystując lata doświadczeń i dyskusji wprowadzono w 1969 r. zapis do Konstytucji, w którym usankcjonowano pomoc finansową rządu federalnego dla ważnych inwestycji landów i gmin, a następnie uchwalona w 1971 r. ustawa rewitalizacyjna (w skrócie - StBauFG) rozpoczęła 20-letni, sformalizowany proces rewitalizacji miast zachodniej części Niemiec, który trwał aż do ich zjednoczenia. Zawarto w niej m.in. zasady formułowania i finansowego wsparcia programów rewitalizacyjnych, pomocy społecznej dla mieszkańców rewitalizowanych terenów oraz ich udziału w tworzeniu programów rewitalizacji. Kompetencje w sferze rewitalizacji nadano od tej pory gminom, które miały otrzymywać finansowe wsparcie z funduszy federalnych i krajowych. Stwierdzono bowiem niekorzystny wpływ wzięcia całego ciężaru odnowy miast na

\footnotetext{
${ }^{2}$ Głównie L. Erharda i K. Adenauera, por. M. Jungblut, Bogaci i superbogaci w RFN, Warszawa 1977.

${ }^{3}$ Ch. Droste, T. Knorr-Siedow, Large Housing Estates in Germany, Policies and practices, RESTATE report 3b I, Utrecht 2004.
} 
barki rządu federalnego, co powodowało m.in. zaniechanie remontów nieruchomości przez prywatnych właścicieli. W ustawie tej zawarte zostały zasady formułowania programów rewitalizacji, subwencjonowania ich funduszami publicznymi, zabezpieczenia mieszkańców rewitalizowanych kwartałów miast i udziału miejscowej ludności w tych programach. Na obszarze wschodnich Niemiec programy rewitalizacji zaczęto realizować dopiero od $1991 \mathrm{r}$.

Zarządzanie całym procesem rewitalizacji przekazywane było przez gminy prywatnym instytucjom powierniczym, które powoływano na mocy dwustronnych umów urbanistycznych. Do ich obowiązków należał m.in. zakup terenów komunalnych. Począwszy od tego okresu aż po dzień dzisiejszy wielki nacisk kładziony był na inwestycje remontowo-budowlane, pozwalające przywracać dawną zabudowę mieszkaniową, dostosowując ją do współczesnych wymogów. Doświadczenia niemieckie wskazują, że rewitalizacja nie jest procesem, który można zakończyć, po pewnym czasie okazuje się, że potrzebne są kolejne działania i nowe programy dostosowane do zmieniających się okoliczności ${ }^{4}$.

Już wtedy zdawano sobie sprawę, że rewitalizacja nie może polegać tylko na fizycznej odnowie zespołu budynków i konieczne jest uzupełnienie odnowy miast pakietem działań społecznych i aktywną ochroną zabytków. Koncepcja ta określona została jako klasyczny model niemieckiej rewitalizacji, będący wynikiem dotychczasowych doświadczeń. W odróżnieniu od innych krajów zachodnich, model ten przewidywał także czasowe ograniczenie praw właścicieli podczas rewitalizacji (co miało zapobiegać spekulacjom), przy jednoczesnym wspomaganiu finansowym inwestycji prywatnych, a także uwzględniał potrzebę zwiększenia partycypacji społecznej w tym procesie. Chodziło m.in. o zachowanie dotychczasowej struktury społecznej na obszarach kryzysowych miast i ułatwienie stworzenia osłony socjalnej dla mieszkańców (zapewnienie lokali zastępczych, pomoc przy przeprowadzkach itp.).

Ciekawą inicjatywę podjęły władze Berlina w latach osiemdziesiątych w wyniku krytycznej oceny dotychczasowych rewitalizacji, polegajacych głównie na wyburzaniu starej zabudowy i zastępowaniu jej nową. Opracowano tzw. 12 zasad ostrożnej rewitalizacji. Wśród nich na uwagę zasługują m.in.: rewitalizacja powinna być jak najszerzej dyskutowana i planowana wspólnie nie tylko z mieszkańcami, ale i przedstawicielami lokalnego handlu i usług. Wszystkie obiekty nadające indywidualne piętno dzielnicy powinny być chronione, a przestrzenie publiczne odpowiednio zaplanowane. Interesujące jest to, że rozszerzenie działań według tych 12 zasad ostrożnej rewitalizacji na pozostałe landy nie przyniosło większych sukcesów, pomimo że w Berlinie ta

\footnotetext{
${ }^{4}$ Podobne wnioski wynikają z doświadczeń brytyjskich. Rewitalizacja prowadzona w latach 60. polegała często na zastępowaniu wyburzanych fragmentów miasta betonową zabudową modernistyczną, która rodziła nowe problemy i po upływie 20-30 lat przystapiono do poprawiania tych błędów.
} 
idea zaowocowała doskonałymi rezultatami. Jest to bardzo pouczająca wskazówka pokazująca, że przenoszenie gotowych rozwiązań na inne tereny, nawet w obrębie jednego państwa, niekoniecznie musi przynieść podobne efekty.

\subsubsection{Rewitalizacja miast niemieckich $w$ okresie ostatnich 20 lat}

\section{Tereny landów wschodnich}

Zjednoczenie Niemiec przyniosło nowe problemy. Wbrew oczekiwaniom wprowadzenie gospodarki rynkowej nie poprawiło wizerunku miast b. NRD, wręcz przeciwnie - upadek większości zakładów przemysłowych spowodował opuszczenie wielu niezagospodarowanych terenów przemysłowych. Ponadto nastapił gwałtowny wzrost bezrobocia, po roku 1995 utrzymującego się na poziomie $20 \%$ przez ponad 10 lat. Proces ten trwa do dziś pomimo nasilonej migracji do landów zachodnich. Migracje te spowodowały pogłębienie się niekorzystnych procesów ludnościowych. Emigrowali głównie ludzie młodzi, energiczni, lepiej wykształceni, a w konsekwencji w miastach wschodnich landów pogorszyła się struktura społeczna mieszkańców. Spadła liczba urodzeń $\mathrm{w}$ związku $\mathrm{z}$ niepewną sytuacją ekonomiczną młodych rodzin i wycofaniem się państwa z pomocy dla rodzin z dziećmi, jaka funkcjonowała w okresie socjalizmu 5 .

Jednocześnie zaobserwowano niekorzystne zjawiska w przestrzeni tych miast. Nowe inwestycje mieszkaniowe, przemysłowe, a także wielkie centra handlowe, podejmowane przez inwestorów z landów zachodnich, realizowano głównie na obrzeżach miast, co przyspieszyło procesy suburbanizacji. Opuszczone przez emigrantów budynki wielo- $\mathrm{i}$ jednorodzinne na peryferiach miast chętnie zajmowane były przez mieszkańców zdewastowanych centrów, a także peryferyjnych osiedli wielkopłytowych. Prestiż osiedli wielkopłytowych, opuszczanych przez migrantów w poszukiwaniu pracy, obniżył się drastycznie, co powodowało ich dalsze wyludnianie się. Podejmowane ogromnym wysiłkiem finansowym próby humanizacji tych osiedli w wielu miastach $b$. NRD, łącznie z Berlinem, przyniosły bardzo ograniczone skutki i wiele takich świeżo zmodernizowanych osiedli trzeba było wyburzać, gdyż koszt ich utrzymania przewyższał czynsze pozyskiwane od nielicznych rodzin, które zechciały w nich pozostać. Jak się okazało, polityka rewitalizacji - humanizacji osiedli wielkopłytowych była błędna. Prowadzono ją na wielką skalę bez uprzedniego należytego rozpoznania procesów ludnościowych, preferencji mieszkańców i ich mobilności.

\footnotetext{
${ }^{5}$ Dla podtrzymania wyższej dzietności kobiet w NRD funkcjonował system wszechstronnej pomocy: subwencjonowane rzeczy dla dzieci - ubrania, wózki, zabawki itp., powszechnie dostępne przedszkola z liczną kadrą - jedna wychowawczyni miała pod opieką tylko kilkoro dzieci, system opieki medycznej itd.
} 
Ogromnym problemem stały się więc pustostany. Dotyczy to nie tylko osiedli wielkopłytowych, ale także starej zabudowy obszarów śródmiejskich. Na przykład w roku $1998 \mathrm{w}$ zabudowie sprzed 1918 r. było niemal 33\% mieszkań niezamieszkanych, nawet $\mathrm{w}$ Berlinie Wschodnim udział ten przekraczał 11\%. W początkach lat dziewięćdziesiątych liczbę niezamieszkanych lokali szacowano na $1,2-1,5 \mathrm{mln}^{6}$. W wielu miastach powodowało to zanik działalności społecznej, zamykanie szkół, przedszkoli, spadek rentowności komunikacji publicznej, zamykanie sklepów, a w konsekwencji unikanie takich dzielnic przez inwestorów.

Dla prywatnych inwestorów na terenie wschodnich landów zaczęto stosować bodźce ekonomiczne w postaci kredytów, gwarancji, odpisów amortyzacyjnych i dopłat ${ }^{7}$.

W celu pobudzenia rozwoju gospodarczego podjęto na szczeblu federalnym wielkie inwestycje $\mathrm{w}$ sferze infrastruktury - w tym unowocześnienie sieci autostrad, dróg i kolei, uruchomiono programy krajowe i federalne $\mathrm{w}$ postaci kredytów i subwencji liczonych w dziesiątkach miliardów marek w latach dziewięćdziesiątych ${ }^{8}$. Duża część $\mathrm{z}$ tych funduszy przeznaczona została na budownictwo mieszkaniowe i to zarówno na remonty istniejącej substancji, jak i na budowę nowych domów. Większość tych inwestycji podjęli inwestorzy $\mathrm{z}$ zachodnich landów. Na terenie b. NRD nie prowadzono żadnych działań rewitalizacyjnych, stąd stopień zaniedbania miast był tak duży, że nadrobienie tych zaległości wymaga znacznie więcej czasu. W końcu lat dziewięćdziesiątych okazało się, że mimo ogromnych nakładów problemy wschodnich landów nie znikły. Nie nastąpił wyraźny wzrost gospodarczy i nie wyrównał się poziom życia między wschodem a zachodem Niemiec. Zradykalizowały się natomiast we wschodnich landach nastroje społeczne, potęgowane wysokim bezrobociem. Ożywiły się grupy i organizacje o charakterze nazistowskim, wzrosła liczba napaści na imigrantów itp.

W odniesieniu do landów wschodnich po zjednoczeniu zastosowano działania, które przyniosły powodzenie w zachodniej części kraju, gdzie od $1971 \mathrm{r}$. działał program Rewitalizacja i Rozwój Budownictwa Miejskiego. W roku 2008

\footnotetext{
${ }^{6}$ Ch. Droste, T. Knorr-Siedow, Large Housing...

${ }^{7} \mathrm{Na}$ szczególną uwagę zasługują odpisy amortyzacyjne - instrument mało w Polsce znany jako regulator gospodarki. W RFN był przez długi czas stosowany i w znakomity sposób przyczynił się do tzw. cudu gospodarczego. Znacznie podwyższone stawki amortyzacyjne w wybranych gałęziach przemysłu (np. w stoczniowym, elektrotechnicznym) umożliwiały firmom niemieckim włączanie ich do kosztów uzyskania przychodów, co pozwalało na zatrzymanie większej części zysków w przedsiębiorstwie. Dzięki temu rosła skłonność do inwestowania i wzrastał popyt na nowe, coraz nowocześniejsze maszyny i urządzenia.

${ }^{8}$ Wykorzystano w tym celu kredyty Europejskiego Funduszu Odbudowy, fundusze w ramach programu Ulepszenie Regionalnej Struktury Gospodarczej, subwencje w ramach programu Wspólne Dzieło Ożywienia Wschodu oraz kredyty grupy banków Kreditanstalt für Wiederaufbau pod zarządem państwowym (odpowiednik polskiego BGK).
} 
program ten dotyczył 488 obszarów miejskich na obszarze starych landów9 Wspierane $\mathrm{w}$ jego ramach działania obejmowały oprócz procesów przygotowawczych - rozmaitych analiz i badań społecznych i przestrzennych wykup i wywłaszczenia terenów, przekwaterowania, organizowanie mieszkań zastępczych, doprowadzanie zdewastowanych terenów do stanu, który umożliwiał podjęcie nowych inwestycji łącznie $\mathrm{z}$ doprowadzeniem infrastruktury technicznej. W roku 1991 program ten został wprowadzony także na terenie b. NRD jako jeden z dwóch programów rządowych. W 2008 r. obejmował 534 tereny miejskie na obszarze nowych landów. Jednak nie przyniósł spodziewanych rezultatów ${ }^{10}$.

Drugim programem rządowym była „Ochrona Zabytków Budownictwa Miejskiego". W roku 2008 obejmował on 177 miast, a zakres działań, oprócz remontów i modernizacji cennych budynków i ich zespołów, dotyczył także ulic i placów o wartościach historycznych i architektonicznych. Zabiegi modernizacyjne $\mathrm{w}$ tych dzielnicach starano się tak ukierunkować, aby możliwe było rozwinięcie w nich działalności biznesu i usług łącznie $\mathrm{z}$ handlem.

W roku 2002 na skutek dotychczasowych niepowodzeń z prostym przeniesieniem zasad odnowy miast $\mathrm{z}$ landów zachodnich, uruchomiono specjalny dla landów wschodnich program Przebudowa Miast Nowych Krajów Związkowych - o bardzo zintegrowanym charakterze ${ }^{11}$. Program ten miał pomóc uporać się z problemami wschodnich Niemiec, które niemal nie występowały w landach zachodnich: znacznej redukcji podaży mieszkań (wyburzenia) i doprowadzenia do stabilizacji rynku mieszkaniowego przy jednoczesnej poprawie atrakcyjności wyludniających się kwartałów i dzielnic. Odbywa się to m.in. poprzez intensywne remonty i modernizację starych części miast z zachowaniem cennej zabudowy wzdłuż głównych ulic, a wobec dużego udziału mieszkań w wielkopłytowych osiedlach, poprawę środowiska mieszkalnego blokowisk - zagospodarowanie pustych przestrzeni, przeprojektowanie przestrzeni publicznych i wyburzenia niektórych fragmentów tych dzielnic.

\section{Przebudowa miast w landach zachodnich po roku 1990}

Nieco wcześniej - po serii eksperymentalnych prób społecznej rewitalizacji w kilku landach i dużych miastach (Berlin, Hamburg, Brema) - w 1999 r. uruchomiono bardzo szczególny, ogólnokrajowy program Kwartały Miejskie o Szcze-

\footnotetext{
${ }^{9}$ M. Bryx, A. Jadach-Sepioło (red.), Rewitalizacja miast..., s. 43

${ }^{10}$ Por. wyżej wspomniany brak powodzenia z rozpowszechnieniem tzw. 12 zasad ostrożnej rewitalizacji w RFN.

${ }^{11}$ N. Krawczyk, M. Modelewska, Kierunki, zakres i efekty rewitalizacji. Studium przypadku - Niemcy Wschodnie, Konferencja w IRM, Kraków 18 września, http://rewitalizacja.org.pl/ dokumenty/konferencja/czwartek_s. 32.pdf, 2008.
} 
gólnym Zapotrzebowaniu na Rewitalizację - Miasto Socjalne. Ma on na celu organizację przestrzeni miasta $\mathrm{z}$ uwzględnieniem problemów społecznych i gospodarczych w strefach problemowych miast, która obejmuje, oprócz poprawy warunków mieszkaniowych, wspieranie przedsiębiorczości wraz z tworzeniem nowych miejsc pracy, poprawę infrastruktury społecznej i przestrzeni publicznych. Jednym $\mathrm{z}$ głównych celów tego programu jest zapobieganie koncentracji ubóstwa i rosnącej segregacji społecznej w miastach niemieckich m.in. poprzez finansowanie tzw. projektów miękkich obejmujących doskonalenie kwalifikacji, podnoszenie zdrowotności, dostęp do kultury, poprawę bezpieczeństwa itp. W 2006 r. dla uzyskania lepszych efektów w tej sferze rząd wprowadził dodatkowy program Zatrudnienie, Oświata i Partycypacja, obejmujący szczególnie dokształcanie i znajomość języka wśród młodych imigrantów, zatrudnianie długotrwale bezrobotnych i pobudzanie partycypacji społecznej. Jak z tego wynika, już wtedy wprowadzona została do polityki miejskiej na szczeblu krajowym idea zintegrowanych programów rewitalizacji prowadzących do odnowy fizycznej, ale także osiągania samodzielności ekonomicznej i ograniczenia problemów społecznych podupadających dzielnic. W 2008 r. programem tym objętych było niemal 500 obszarów na terenie miast w całych Niemczech.

W następnych latach uruchamiano następne programy: po pozytywnej ocenie uruchomionego dwa lata wcześniej programu dotyczącego miast wschodnich Niemiec, w 2004 r. uruchomiono pilotażowy program dla zachodnich landów Przebudowa Miast Starych Krajów Zwiazkowych, a w 2008 r. obejmujący całe Niemcy - Aktywne Centra Miejskie, w którym chodzi o zachowanie istniejącej substancji i stworzenie warunków dla aktywności gospodarczej, kulturalnej i rozrywkowej w centralnych dzielnicach miast, co prowadzi do uatrakcyjnienia dzielnic śródmiejskich. Program ten jest realizowany poprzez modernizację obiektów nadających indywidualny ton miastu i uatrakcyjnienie przestrzeni publicznej, w tym dzięki wspieraniu porządkowania i zabudowy działek niezagospodarowanych.

Dzięki tym programom udało się zmniejszyć wydatnie liczbę pustostanów - głównie poprzez wyburzenia, przy jednoczesnej dbałości o zachowanie zabytkowej zabudowy oraz poprawić środowisko mieszkalne zarówno w starych dzielnicach, jak i w osiedlach wielkopłytowych. Rynek mieszkaniowy stał się bardziej ustabilizowany dzięki podjęciu wielostronnych działań i skoordynowanych instrumentów ekonomicznych. Również w roku 2008 uruchomiony został Pakt Inwestycyjny dla Modernizacji Energetycznej Infrastruktury Socjalnej, który praktycznie dotyczy termoizolacji budynków użyteczności publicznej ${ }^{12}$.

\footnotetext{
${ }^{12}$ Interesujące jest to, że w tym samym roku, 21 listopada 2008 r. w Polsce uchwalona została ustawa o termomodernizacji, która ma szerszy zasięg oddziaływania i obejmuje budynki
} 


\section{Cechy wspólczesnej rewitalizacji w Niemczech}

Obecnie, po 40 latach nieprzerwanej i zinstytucjonalizowanej rewitalizacji miast niemieckich, która w znaczącym stopniu finansowana jest $\mathrm{z}$ budżetu federalnego, cele rewitalizacji można określić w kilku punktach:

1) wzmocnienie rangi i prestiżu centrów miast,

2) stworzenie trwałych, ekonomicznych podstaw do odnowy i dalszego samodzielnego funkcjonowania podupadłych części miast, łącznie z opuszczonymi terenami poprzemysłowymi, pomilitarnymi itp.,

3) ochrona zabudowy zabytkowej i cennej z historycznego punktu widzenia,

4) zapewnienie pakietu społecznego dla grup mieszkańców zagrożonych wykluczeniem społecznym na obszarach zdegradowanych (dotyczy sfery edukacji, zdrowia, bezpieczeństwa, bezrobocia, pomocy społecznej itp.)

W odróżnieniu od Polski, programy rewitalizacji w wysokorozwiniętych krajach Zachodniej Europy zostały zainicjowane na szczeblu rządowym i stanowią istotną część kompleksowej polityki miejskiej. Są zarządzane i wspomagane finansowo ze szczebla krajowego. Również w Niemczech procesy rewitalizacji są sterowane przez dwie instytucje rządowe: Ministerstwo Transportu, Budownictwa i Rozwoju oraz Federalny Urząd Budownictwa i Ładu Przestrzennego. Ze względu na to, że procesy rozwojowe miast obejmują wiele dziedzin, które podlegają różnym resortom, wspomniane ministerstwo ściśle współpracuje z innymi ministerstwami przy opracowywaniu koncepcji programów rewitalizacji na szczeblu państwowym oraz koordynacji wydatków z różnych funduszy na terenie miast: $z$ Ministerstwem Ochrony Środowiska, Ministerstwem Nauki i Badań i z Ministerstwem Pracy i Polityki Społecznej. Ministerstwa te mają z kolei silne wsparcie różnych instytucji i wielu instytutów badawczych, co ułatwia modyfikowanie dotychczasowej polityki i podejmowanie właściwych decyzji.

Wspomniany Federalny Urząd Budownictwa i Ładu Przestrzennego zajmuje się analizami informacji ze sfery rozwoju miast, w tym rewitalizacji. Ważną rolę odgrywa zlokalizowany pod Berlinem Instytut Rozwoju Regionalnego i Planowania Strukturalnego (IRS), a także stworzone przy tym instytucie Centrum Wymiany Informacji o Procesach Rewitalizacji we Wschodnich Landach, które początkowo miało zapewniać powszechny dostęp do informacji $\mathrm{w}$ tej dziedzinie $\mathrm{z}$ terenu landów wschodnich. Jego działalność jest rozszerzona o monitorowanie procesów rewitalizacji, a także wspieranie edukacji i promocję w tej dziedzinie we Wschodnich Niemczech. Autorzy książki Rewitalizacja

wszelkiego typu. Podobne przepisy wprowadzono także na Węgrzech, obejmują one jednak mniej grup budynków. 
miast $w$ Niemczech ${ }^{13}$ wymieniają jeszcze dwa ważne instytuty: Instytut Badań Miejskich i Polityki Strukturalnej oraz Niemiecki Instytut Urbanistyki.

Funkcjonowanie takich instytutów i szczegółowa statystyka sięgająca do niewielkich fragmentów miast jest podstawą wszelkich analiz zmian przestrzennych i społecznych wewnątrz miast, a tym samym stanowi niezbędną bazę do identyfikacji obszarów problemowych w miastach i monitorowania zmian zachodzących w wyniku działań rewitalizacyjnych.

Cechą charakterystyczną niemieckiego ustroju jest duża autonomia poszczególnych landów, co objawia się również w różnorodności regionalnych urzędów odpowiedzialnych za politykę miejską i rewitalizację. Należą do nich np. Ministerstwo Spraw Wewnętrznych (Bawaria), Ministerstwo Spraw Wewnętrznych i Sportu (Nadrenia-Palatynat), Ministerstwo Środowiska (Saara), Ministerstwo Budownictwa i Transportu (Turyngia, Północna Nadrenia-Westfalia), Ministerstwo Infrastruktury i Ładu Przestrzennego (Brandenburgia) itp.

Mimo że państwo inicjuje i w znacznym stopniu finansuje procesy odnowy miast (rewitalizacja finansowana jest w ok. 33\% z budżetu federalnego), kompetencje w sferze organizacyjnej scedowane są na poziom regionalny i lokalny. Jak już wyżej wspomniano, gminy zawierają umowy z powiernikami (operatorami) rewitalizacji, którymi najczęściej są prywatne przedsiębiorstwa komunalne działające albo na rachunek własny, albo w imieniu gminy.

W procesy rewitalizacji angażują się obok instytucji, dla których jest to obowiązkiem, także inni uczestnicy - policja, opieka społeczna, przedsiębiorcy, firmy budowlane (najczęściej wielkie) i społeczność lokalna, której udział jest stymulowany rozmaitymi środkami przez państwo. Wielką rolę odgrywają organizacje pozarządowe, które, podobnie jak we Francji, skupiają pasjonatów i entuzjastów różnych idei, są inicjatorami wielu ciekawych rozwiązań i prowadzą bardzo profesjonalne działania.

Trudno jest prowadzić proces rewitalizacji bez pełnego zaangażowania właścicieli nieruchomości na zaniedbanych obszarach. Jeśli rozwiązania prawno-finansowe są niewystarczające lub zniechęcające, postawa właścicieli może stać się przeszkodą lub barierą dla procesu rewitalizacji ${ }^{14}$. W Niemczech, z powodu dużej liczby i rozproszenia, prywatnych najemców i właścicieli reprezentuje Związek Właścicieli Gruntów i Nieruchomości. Problemem jest np. wyburzanie pustostanów, na których ustanowiona jest hipoteka i banki w obawie przed stratami nie zgadzają się na rozbiórki obciążonych kredytami budynków. Dlatego niezwykle ważne jest rozeznanie, z jakimi typami właścicieli współpra-

${ }^{13}$ M. Bryx, A. Jadach-Sepioło, Rewitalizacja miast...

${ }^{14}$ Takie były np. w Polsce skutki uchwalenia ustawy z dnia 28 lipca 2005 r. o partnerstwie publiczno-prywatnym, która dawała nadmierne przywileje władzy publicznej, co kompletnie zniechęciło prywatnych przedsiębiorców do angażowania się we wspólne inwestycje z sektorem publicznym (PPP). 
cuje się na terenie rewitalizowanym i jakie są ich zamiary. Właścicieli nieruchomości w miastach niemieckich podzielono na trzy grupy:

1) dbających o stałą poprawę stanu swoich obiektów - albo zamieszkujących te nieruchomości, albo modernizujących je w celu uzyskania wysokich czynszów, a także firmy, korporacje, będące w posiadaniu budynków;

2) grupę stanowiącą większość właścicieli (60-80\%) dbających o utrzymanie nieruchomości w stanie nie pogorszonym;

3) tych, którzy zamierzają pozbyć się swojej własności, niezainteresowanych modernizacją i inwestycjami.

Od tego, jakie są proporcje poszczególnych grup właścicieli i ich postawy, zależy szybkość przebiegu i jakość procesu rewitalizacji i aby w tych właścicielach mieć sprzymierzeńców, trzeba stosować różne argumenty i instrumenty oddziaływania, w tym także na społeczność lokalną.

Niesłychanie ważnym partnerem wspomagającym poczynania rewitalizacyjne są w Niemczech przedsiębiorcy prywatni. Nawet w tak bogatym kraju jak Niemcy finansowanie całości rewitalizacji z budżetu państwa doprowadziło do kryzysu i w rezultacie już w r. 1971 zaczęto rozkładać jej ciężar również na władze krajów związkowych i gmin. Jednak zaangażowanie prywatnych osób i firm pozwala na zwielokrotnienie funduszy wspomagających procesy rewitalizacji. Partnerstwo publiczno-prywatne (PPP) jako jedna $\mathrm{z}$ form włączania kapitału prywatnego do procesu rewitalizacji jest w Niemczech w ostatnich latach intensywnie rozwijane. Do współpracy z samorządami lokalnymi zapraszani są, oprócz wyżej wspomnianych właścicieli nieruchomości i najemców, także architekci, projektanci, urbaniści, firmy deweloperskie i budowlane. Współpraca ta nie odbywa się bez konfliktów, wynikających z rozbieżnych interesów, jednak znacznie zwiększa ona możliwości realizacji, a z nielicznymi wyjątkami przyspiesza proces rewitalizacji i zmniejsza obciążenie finansów publicznych.

Przejmowanie steru zarządzania rewitalizacją przez firmy prywatne w Niemczech prowadzi do większej efektywności, gdyż są one zainteresowane szybszym tempem prac, a jednocześnie wnoszą do tego partnerstwa swoje doświadczenie. Jest to szczególnie cenne, gdyż w procesie rewitalizacji nieustannie pojawiają się niespodziewane przeszkody i problemy, których pokonywanie może wydłużać jego realizację nawet o wiele lat ${ }^{15}$.

${ }^{15}$ W Polsce przykładem takich opóźnień może być próba rewitalizacji Targu Siennego i Rakowego w Gdańsku. W ciągu 10 lat od podpisania listu intencyjnego nie zdołano wyjść poza wstępną koncepcję programową. (D. Załuski, Tereny pokolejowe PKP S.A. - szanse i możliwości przeksztatceń w nowe funkcje miejskie, [w:] W. Jarczewski, (red.), Przestrzenne aspekty rewitalizacji - śródmieścia, blokowiska, tereny poprzemystowe, pokolejowe $i$ powojskowe, seria: Rewitalizacja Miast Polskich, t. 4, Kraków 2009, s. 237-238.). Podobny jest skutek działania firmy Synergia 99 na terenach postoczniowych (73 ha) w Gdańsku. 
Pozytywnym przykładem jest, realizowany aktualnie, duży projekt w Chemnitz, gdzie włączonych do PPP jest kilka prywatnych spółek budowlanych i komunalnych. Łączny koszt realizacji tego projektu wyceniono na ponad 240 milionów euro $\mathrm{w}$ okresie ok. 20 lat, w tym ok. 30\% wydatkowane będzie z funduszy publicznych, być może część kosztów zostanie sfinansowana z funduszy unijnych. Program przewiduje m.in. wyburzenie ok. 27 tys. mieszkań - pustostanów. W tym przypadku bardzo korzystny może się okazać udział jednej $\mathrm{z}$ dużych prywatnych firm budowlanych $\mathrm{w}$ organizacji pomocy dla mieszkańców wyburzanych mieszkań, dla których trzeba stworzyć możliwość zamieszkania w nowych warunkach (przejściowo, na czas odtwarzania „ich” mieszkań lub na stałe) ${ }^{16}$.

Wieloletnie doświadczenie władz niemieckich w sferze odnowy i rewitalizacji miast pozwoliło na wypracowanie pewnych schematów postępowania. Jednym $\mathrm{z}$ nich jest strategiczne podejście do tego procesu. Jest on najczęściej przewidziany na wiele lat, wobec tego stanowi integralną część polityki miejskiej koordynowanej i sterowanej na szczeblu państwowym. W ramach takiej strategii formułowane są cele ogólne, przekładane następnie na konkretne działania. Zakłada się udział różnorodnych podmiotów, władz różnego szczebla, instytucji i organizacji pozarządowych, przedsiębiorstw i lokalnej społeczności. Muszą być określone koszty i źródła ich pokrycia. Niezadowalające rezultaty początkowych prób rewitalizacji doprowadziły do powstania programu o charakterze zintegrowanym - Kwartały Miejskie o Szczególnym Zapotrzebowaniu na Rewitalizację - Miasto Socjalne, w którym, obok tworzenia podstaw ekonomicznych dalszego funkcjonowania obszaru kryzysowego, określany jest cały pakiet działań społecznych w sferze kultury, edukacji, bezpieczeństwa, opieki społecznej.

Organizacyjnie za proces zarządzania rewitalizacją w konkretnym mieście odpowiada burmistrz lub w dużych miastach urząd planowania urbanistycznego, natomiast konkretne działania niemal we wszystkich landach powierzane są spółkom, realizującym projekty na rzecz gminy. Są one powiernikami rewitalizacji (operatorami), którzy wykupują grunty, utrzymują kontakt z lokalną społecznością, prowadzą negocjacje z inwestorami itp. Inwestorzy ci muszą uzyskać zezwolenie na realizację swoich zamierzeń na rewitalizowanym obszarze.

${ }^{16}$ Rewitalizacja Chemnitz (do 1990 r. Karl-Marx-Stadt) jest pouczająca dla Polski. Miasto specjalizowało się dawniej we włókiennictwie i podobnie jak w Łodzi przemysł ten upadł. Niektóre obiekty poprzemysłowe zrewitalizowano, przekształcając je w obiekty wystawowe i muzea związane z włókiennictwem. Miasta jednak nie stać na ich utrzymanie i prosperują one głównie dzięki dawnym pracownikom - pasjonatom, często emerytom, którzy są społecznymi kustoszami, przewodnikami i konserwatorami maszyn i urządzeń. Stanowi to przestroge przed zbytnim optymizmem entuzjastów rewitalizacji, polegającej na przesyceniu obiektów modernizowanych funkcją kulturalną, która z nielicznymi wyjątkami musi być finansowana ze środków publicznych. Jednym z podstawowych wymogów skutecznej rewitalizacji powinno być zapewnienie pewnej samowystarczalności ekonomicznej danego obszaru. 
Jednym z wniosków, jakie można wysnuć z przebiegu rewitalizacji miast niemieckich jest konieczność dobrego rozeznania rynku nieruchomości, w tym także preferencji i zamiarów potencjalnych inwestorów. $Z$ jednej strony gmina ma obowiązek utrzymania cen gruntów w pewnych granicach, zapobiegając spekulacji. $Z$ drugiej strony zbyt późne dopuszczanie prywatnych inwestorów do działania na rewitalizowanym terenie prowadziło do nieporozumień i konfliktów. Wynika stąd potrzeba jak najwcześniejszego konsultowania się z lokalnymi właścicielami nieruchomości i potencjalnymi inwestorami już na etapie założeń i wstępnych koncepcji rewitalizacji. Najlepiej jest, gdy współpraca taka jest organizowana we wszystkich stadiach całego procesu. Pozwala to uniknąć nieporozumień i sporów $\mathrm{w}$ trakcie rewitalizacji, które, jak pokazują również przykłady brytyjskie, mogą opóźniać rewitalizację o wiele lat.

\section{Finansowanie rewitalizacji}

Jak wspomniano wyżej, zarówno nowy zapis w Konstytucji z 1969 r. sankcjonujący pomoc finansową $z$ funduszy federalnych dla najważniejszych inwestycji gmin i krajów związkowych, jak również ustawa rewitalizacyjna z $1971 \mathrm{r}$. umożliwiły subwencjonowanie procesów rewitalizacji miast ze szczebla centralnego. Finansowanie programów rewitalizacji w Niemczech ma od tej pory bardzo silne umocowanie prawne. Zmiany legislacyjne doprowadziły też do corocznego uchwalania dokumentu rządowego o wspieraniu działań rewitalizacyjnych oraz nowych zapisów w prawie budowlanym (1987). Spójność tych dokumentów znacznie ułatwia finansowanie i przebieg procesów rewitalizacyjnych.

Zasada, jaką przyjęto od początku lat 70., polega na tym, że programy rewitalizacji finansowane są po jednej trzeciej $\mathrm{z}$ budżetu federalnego, krajów związkowych i gmin. Oprócz tego wspierane mogą być z rozmaitych innych źródeł: np. na szczeblu krajowym z funduszu wspierania budownictwa mieszkaniowego, z kredytów sterowanego przez państwo Kreditanstalt für Wiederbau, ze szczebla krajów związkowych z przeróżnych funduszy przeznaczanych na ochronę dziedzictwa kulturowego, na rozwój i rewitalizację miast, poprawę środowiska mieszkaniowego i innych. Gminy inicjujące programy rewitalizacyjne zapewniają swój wkład (33\%) z własnego budżetu. Istnieje ponadto wiele możliwości wsparcia tych programów $\mathrm{z}$ innych źródeł: $\mathrm{w}$ ostatnich dwóch okresach budżetowych Unii Europejskiej z programu URBAN I i URBAN II skorzystało wiele miast niemieckich ${ }^{17}$. Podobnie pomocne były dotychczas inne unijne programy, np. INTERREG i EQUAL.

${ }^{17}$ Środki unijne dla poszczególnych państw członkowskich na rewitalizację miast w ramach programów URBAN przyznawane były w proporcji do liczby ludności tych państw, stąd najwięcej miast skorzystało z nich w Niemczech - najludniejszym kraju Unii Europejskiej. W momencie akcesji Polski do UE programy te były już niedostępne. 
Istnieje też grupa krajowych środków na tzw. miękkie programy, funkcjonujących na szczeblu federalnym oraz na szczeblu krajów związkowych, przeznaczanych np. na wspieranie kształcenia i szkolnictwa, polityki zatrudnienia, rozwoju przedsiębiorczości, programów dla młodzieży. Są one włączane do programów rewitalizacji obok środków komunalnych przeznaczanych na poprawę jakości życia. Niezależnie od tych funduszy, procesy rewitalizacji wspomagane są środkami rozmaitych organizacji pozarządowych i fundacji, a także poważnie zasilane przez osoby i firmy prywatne.

Wspomnieć należy też o specyficznym dla Niemiec Wschodnich problemie, który udało się rozwiązać dopiero po 10 latach od zjednoczenia. Załamanie rynku pracy, masowe migracje powodujące dalsze deformowanie struktury demograficznej nowych wschodnich landów, zaowocowało setkami tysięcy opuszczonych mieszkań w wielkich osiedlach wielkopłytowych i zaniedbanych centrach miast. Czynsze nie pokrywały kosztów eksploatacji tych budynków, a koszty rozbiórki obciążające konta spółdzielni mieszkaniowych i przedsiębiorstw budowlanych powodowały popadanie tych jednostek w zadłużenie. Sprawa komplikowała się z powodu oporu banków - wiele budynków miało obciążone hipoteki, a mieszkańcy je opuścili. Masowe wyburzenia groziły wówczas bankom dużymi stratami z powodu znikania majątku, z którego miał być spłacany kredyt. W ten sposób procesy rewitalizacji napotykały silnego przeciwnika. Nowelizacja ustawy w 2000 r. pozwoliła na rozwiązanie tego problemu, poprzez współfinansowanie przez państwo tych wyburzeń i ułatwianie restrukturyzacji zadłużenia.

Dużą wagę przywiązuje się do określania kosztów zamierzonej rewitalizacji. Próbowano koszty te pogrupować w trzy typy planowanych wydatków. Koszty bezinwestycyjne - obejmują fazy przygotowawcze, w tym badania i raporty $z$ tych badań, konferencje i kontakty z innymi miastami dla skorzystania $\mathrm{z}$ ich doświadczenia. Do kosztów tych zaliczano także koncepcyjne prace urbanistyczne, w tym związane z polityką rozwoju całego miasta, kierowanie procesem rewitalizacji, jak również działania w celu zapewnienia partycypacji społecznej w programie. Zasadniczą grupą kosztów są koszty inwestycji: wyburzenia, remonty i modernizacje budynków, poprawa komunikacji, przestrzeni publicznej. Trzecią grupę tworzą tzw. koszty pośrednie, obejmujące zakupy terenów i ewentualnie przeprowadzki mieszkańców. Dla każdego typu działań starano się określić szacunkowe wartości nakładów, co pozwalało łatwiej zrealizować zamierzenia rewitalizacyjne bez nadmiernej straty czasu. Wydłużenie w czasie procesu rewitalizacji skutkowało najczęściej znacznym wzrostem kosztów, czego doświadczono również w Anglii.

Począuszy od $1971 \mathrm{r}$. obowiązuje zasada, że programy rewitalizacji miast finansowane są w równej części przez budżet federalny (33\%), kraje związkowe (33\%) i gminy (33\%). Do połowy lat osiemdziesiatych budżet federalny przeznaczał na te programy fundusze stopniowo rosnące od $100 \mathrm{mln}$ DM 
w 1971 r. do $330 \mathrm{mln}$. DM w roku 1985. Przez dwa kolejne lata poziom wydatków na te cele wzrósł do 1 mld DM, a przez kolejne trzy (1988-1990) zmniejszył się do 660 tys. DM. Wielkości te dotyczą tzw. starych landów w b. RFN.

W momencie zjednoczenia Niemiec sytuacja zmieniła się. W latach 19932000 na stare landy przeznaczano jedynie $80 \mathrm{mln}$ DM rocznie, kierując znacznie wyższe kwoty na wsparcie odnowy miast w nowych landach wschodnich Niemiec. Z czasem polityka ta przyniosła rosnące protesty landów zachodnich, w których na skutek deindustrializacji było wciąż wysokie bezrobocie i miasta, na skutek zamykania kopalń i fabryk, podupadały. Począwszy od roku 2001 kwoty na rewitalizację dla zachodnich krajów związkowych z budżetu federalnego zaczęły wyraźnie wzrastać. Jeśli jednak porównamy kwoty, jakie łącznie przeznaczono na wsparcie procesów rewitalizacji, to w landach zachodnich w całym okresie 1971-2002 wydano ok. 9 mld DM, a w landach wschodnich tę samą kwotę wydano w okresie znacznie krótszym (1990-2002).

Dla procesu rewitalizacji w Niemczech duże znaczenie miało zaangażowanie środków prywatnych. Lokowane one były głównie w dochodowe działalności na rewitalizowanych obszarach, dzięki czemu poprawiała się sytuacja gospodarcza zaniedbanych terenów miejskich. Szacunkowo można określić, że każde euro wydatkowane $\mathrm{z}$ budżetu federalnego i krajów związkowych pociągnęło za sobą inwestycje prywatne 6,5 do 9 razy wyższe (w różnych okresach i na różnych obszarach). Tylko w okresie 1995-2006 wartość prywatnych inwestycji na obszarach rewitalizowanych w całych Niemczech przekroczyła 80 mld euro. Jeśli dodamy do tej kwoty wsparcie, jakie uzyskały miasta niemieckie w tym samym okresie ze wszystkich funduszy publicznych (ponad 23,5 mld euro), suma łącznych wydatków na rewitalizację w latach 1995-2006 przekroczy wyraźnie 100 mld euro $^{18}$.

\section{Ocena, monitoring i partycypacja społeczna}

Ze względu na wielką skalę wsparcia procesów rewitalizacyjnych funduszami publicznymi istnieje potrzeba monitorowania i obiektywnej oceny przebiegu i rezultatów tych procesów. Potrzebne do tego stały się dane statystyczne dla wyznaczonych fragmentów miast, których zebranie - nawet w warunkach niemieckich - nie jest łatwe. Dodatkowym utrudnieniem jest wielka różnorodność programów rewitalizacyjnych, które powinny być oceniane różnymi miernikami. Powoduje to konieczność zbierania danych statystycznych, specyficznych dla danego obszaru. Niektóre procesy nie dają się ocenić metodami ilościowymi, konieczne jest stosowanie analiz jakościowych, $\mathrm{z}$ założenia bardziej subiektywnych. Przy tworzeniu systemu monitoringu wykorzystane

\footnotetext{
${ }^{18}$ M. Bryx, A. Jadach-Sepioło (red.) Rewitalizacja miast..., s. 38-39.
} 
zostały doświadczenia unijne, zastosowane do oceny skutków programu URBAN (realizowanego w latach 1994-1999 oraz 2000-2006). Budowa systemu monitoringu na wielu obszarach jest jeszcze w toku.

Doświadczenia wielu krajów, w tym także Niemiec, wskazały, że czynnikiem $\mathrm{w}$ istotny sposób wspomagającym przebieg procesów rewitalizacji jest zaangażowanie społeczności lokalnej. Chcąc zapewnić sobie poparcie społeczne, w krajach zachodniej Europy i w Niemczech wypracowano całą gamę środków komunikacji władz z mieszkańcami, które $\mathrm{w}$ efekcie mogą wywołać efekt synergii ${ }^{19}$.

Do środków tradycyjnej komunikacji z mieszkańcami stosowanych w różnych miastach należą rozmaite formy spotkań bezpośrednich - rozmowy, zebrania, organizowanie forum mieszkańców, tzw. warsztaty. Specyficzną formą takich warsztatów są warsztaty Charette, których idee przenikły już do Polski. Zastosowano je np. przy pracach nad rewitalizacją niektórych dzielnic w Poznaniu ${ }^{20}$ i w Krakowie. W pierwszym przypadku uczestnikami tych spotkań byli, obok władz miasta, naukowców i mieszkańców, także studenci wydziału architektury i urbanistyki, którzy przedstawiali swoje wizje poprawy przestrzeni w danej części miasta. W przypadku Krakowa wciągnięto do współpracy dzieci i młodzież szkolną, która przedstawiała swoje pomysły i rysunki z własną wizją zagospodarowania parku dla dzieci.

\subsection{Francja}

\subsubsection{Początki rewitalizacji powiązanej z programem mieszkalnictwa}

Proces rewitalizacji zdegradowanych części miast we Francji trwa niewiele krócej niż w Anglii. Początkowo polityka państwa, podobnie jak w Anglii, skupiona była na odnowie fizycznej starych i zaniedbanych dzielnic mieszkaniowych, co trwało niemal do końca XX w. Zniszczenia wojenne spowodowały

${ }^{19}$ Przykładem może być postawa mieszkańców osiedla Wrzeciono na warszawskich Bielanach. Władze gminy, proponując poprawę niektórych elementów wyposażenia osiedla wciagnęły do współpracy aktywnych mieszkańców, co zaowocowało nie tylko ich współuczestnictwem na etapie planowania, ale także spowodowało pewien niewielki udział finansowy wspólnot mieszkaniowych w proponowanych ulepszeniach na tym terenie (osiedle to zamieszkane jest w znacznej mierze przez ludzi o bardzo niskich dochodach) i wyraźny wzrost dbałości o nowe urządzenia mieszkańcy zaczęli je traktować jak swoje (wywiad z burmistrzem Bielan w ramach programu RESTATE, w którym autor uczestniczył w latach 2002-2005).

${ }^{20} \mathrm{http}: / /$ www.poznan.pl/mim/public/s8a/pages.html?co=list\&id=1025\&ch=1035\&instance=1017 \&lang=pl por. także http://www.muratorplus.pl/biznes/wiesci-z-rynku/przyjazne-ludziom-i-przyrodzie_63671.html. Por. też ReUrbanizacja, wyd. przez Urząd Miasta Lipska, Lipsk-Kraków 2005, polskie thum. przygotowane przez Instytut Rozwoju Miast. 
nie tylko konieczność odbudowy infrastruktury i budynków, ale także wyburzenia i zastępowanie zdewastowanych obiektów nowymi. Od I wojny światowej funkcjonował program budowy tanich mieszkań (HBM), a krótko po II wojnie światowej, wobec dużego deficytu mieszkań, znacznie rozbudowany został program HLM (budowy mieszkań o niewygórowanych cenach). Wtedy zapoczątkowany został program budowy wielkich osiedli mieszkaniowych na peryferiach miast, realizowany zgodnie z urbanistycznymi zaleceniami Karty Ateńskiej.

Dopiero w latach dziewięćdziesiątych zaczęto wprowadzać do programów rewitalizacji także rozwiązywanie problemów społecznych i pobudzanie rozwoju gospodarczego ${ }^{21}$. Pomimo ciagłego wspomagania odnowy substancji mieszkaniowej przez państwo ( $\mathrm{w}$ tym także masowych wyburzeń starych, substandardowych budynków) jeszcze $\mathrm{w}$ początkach lat siedemdziesiątych istniało we Francji ponad $6 \mathrm{mln}$ mieszkań niekomfortowych. Początkowo próbowano poprawić stan budynków w centrach miast poprzez różne administracyjne zarządzenia i nakazy, z czasem politykę tę zmieniono, stosując zachęty w postaci subwencji, pożyczek, obniżki podatków itp. Zaowocowało to zwiększeniem inwestycji dokonywanych przez właścicieli kamienic, najczęściej zabytkowych, w miastach historycznych.

Już w 1945 r. powołany został Krajowy Fundusz Poprawy Mieszkalnictwa (FNAH), który z czasem został zasilony podatkiem od niektórych czynszów, co miało $\mathrm{w}$ zamierzeniu przynieść większe urynkowienie wynajmu mieszkań. Liczba mieszkań objętych działaniem tego funduszu stopniowo malała, a krytyka jego działalności doprowadziła do zastapienia go przez nową instytucję - Krajową Agencję ds. Poprawy Mieszkalnictwa (ANAH, powstałą w 1971 r.), co przyczyniło się do uaktywnienia polityki poprawy starych, przedwojennych zasobów mieszkaniowych. Agencja ta usprawniła współpracę samorządów z rządem i prywatnymi właścicielami mieszkań, zarządzając m.in. budynkami, w których czynsz był dodatkowo opodatkowany na zasilanie krajowego Funduszu Remontowego. Działalność instytucji (obok rozwiązań fiskalnych), która przyczyniła się do finansowego wspomagania wielkiej liczby remontów mieszkań prywatnych $\mathrm{z}$ funduszy publicznych, jest do dzisiaj wysoko oceniana ${ }^{22}$.

${ }^{21} \mathrm{~W}$ dużym stopniu pod wpływem zamieszek, wybuchających co pewien czas w miastach różnych części Francji.

${ }^{22}$ Można się tu dopatrzyć podobieństwa do funkcjonującej w Polsce w latach 90. tzw. dużej ulgi budowlano-remontowej, która skłoniła setki tysięcy właścicieli do podjęcia remontów swoich domów i mieszkań dzięki finansowej pomocy państwa. Niestety kolejny rząd lewicowy tę ulgę zlikwidował, uzasadniając swą decyzję tym, że „nie będzie finansował złotych klamek w mieszkaniach bogatych ludzi”. Ulga ta przyczyniła się do znaczącego pobudzenia produkcji materiałów budowlanych i wyposażenia mieszkań oraz usług remontowych, stanowiąc koło zamachowe rozwoju tego działu gospodarki. 
W latach sześćdziesiątych i siedemdziesiątych rząd położył duży nacisk na rewaloryzację zabytkowych części miast, stopniowo wspomagając ekonomiczny i społeczny rozwój zdegradowanych śródmieść. W tym okresie równolegle rozbudowywane były przedmieścia dużych miast (głównie poprzez budowę dużych modernistycznych osiedli mieszkaniowych) w celu zaspokojenia szybko rosnących potrzeb mieszkaniowych, a jednocześnie rozpoczęto proces odnowy starych, zaniedbanych centrów w miastach historycznych. Szczególne miejsce $\mathrm{w}$ polityce rozwoju miast $\mathrm{i}$ ich rewitalizacji poświęcono miastom małym i średnim.

Pierwsze działania objęły zaledwie część ze 100 tzw. Sektorów Chronionych w Miastach Historii i Sztuki. Sektory te stanowią centra historyczne, wytypowane przez Ministerstwo Kultury oraz konserwatorów i architektów zajmujących się ochroną cennych historycznie zespołów zabytkowych.

W okresie tym zaczęto uruchamiać oszczędności ludności, aby przy finansowym wsparciu państwa przyspieszyć proces modernizacji i budowy nowych mieszkań. Aktualnie lista tych historycznych sektorów miejskich w całej Francji obejmuje wciąż blisko sto terenów, a zdecydowana ich większość zlokalizowana jest $\mathrm{w}$ miastach małych $\mathrm{i}$ średnich ${ }^{23}$. Wynikało to $\mathrm{w}$ dużym stopniu z ogólnej polityki miejskiej państwa. W okresie powojennym obserwowano bowiem nadmiernie dynamiczny rozwój Paryża, co w latach sześćdziesiątych wywołało potrzebę zahamowania tego procesu poprzez stymulowanie rozwoju innych dużych centrów regionalnych, a w następnym okresie, wobec wyludniania się terenów wiejskich, także pobudzanie rozwoju miast średnich i małych.

W polityce wobec wymienionych wyżej Sektorów Chronionych w Miastach Historii i Sztuki zastosowano różne instrumenty mające poprawić ich wygląd i funkcjonowanie. Właściciele zabytkowych obiektów na tych terenach moga liczyć na pomoc finansową ze strony państwa w przypadku podjęcia rewaloryzacji posiadanych budynków ${ }^{24}$.

Działania podejmowane są zazwyczaj na obszarze kilku kwartałów ulic, co pozwala skoncentrować wysiłki i szybko uzyskać pożądane rezultaty. Stopniowo standardowy program dla wszystkich tych sektorów był uzupełniany o kolejne, lokalne działania, polegające m.in. na porządkowaniu przestrzeni publicznej,

${ }^{23}$ Por. T. Marszał, S. J. Kozłowski, Zagospodarowanie malych miast Polski Środkowej - kontekst rewitalizacji, [w:] J. Poczobut (red.), Specyfika odnowy matych i średnich miast w Polsce, Kraków 2008.

${ }^{24}$ W Polsce jeszcze nie do końca społeczeństwo akceptuje zasilanie remontów prywatnych kamienic z funduszy publicznych. Znajduje to odbicie w decyzjach urzędowych: krakowska izba obrachunkowa nie wydała zgody na dofinansowanie z budżetu miasta remontów prywatnych kamienic zabytkowych w Krakowie, ale np. Łęczyca w woj. łódzkim takie pozwolenie uzyskała. 
poprawie estetyki wystaw sklepowych, nawierzchni ulic, małej architektury itp. W sferze gospodarczej starano się przemieszać rozmaite funkcje miejskie, rozwijać handel i turystykę w centrach historycznych, tworzyć partnerstwo $\mathrm{z}$ inwestorami prywatnymi, a także wzmocnić transport publiczny.

W latach 1976-1982 w następstwie kryzysu światowego, spowodowanego ograniczeniem dostaw ropy naftowej, rząd Francji ograniczył pomoc finansową dla sfery mieszkalnictwa, mimo że istniało jeszcze wiele obszarów zabudowy substandardowej. W końcu tego okresu podjęte zostały działania mające na celu większe zrównoważenie rozwoju urbanistycznego i społecznego miast, w tym m.in.: utrzymanie istniejących struktur społecznych w miastach dzięki objęciu pomoca grup społecznych zagrożonych wykluczeniem, powiązanie miast z ich otoczeniem, kształtowanie krajobrazu miejskiego i zwiększenie wysiłków w sferze ochrony zabytków, a także coraz powszechniejsze zwiększanie roli centrów miast poprzez ich rewitalizację. Zaczęto dostrzegać potrzebę poprawy przestrzeni publicznych i pobudzania rozwoju ekonomicznego w skali poszczególnych dzielnic.

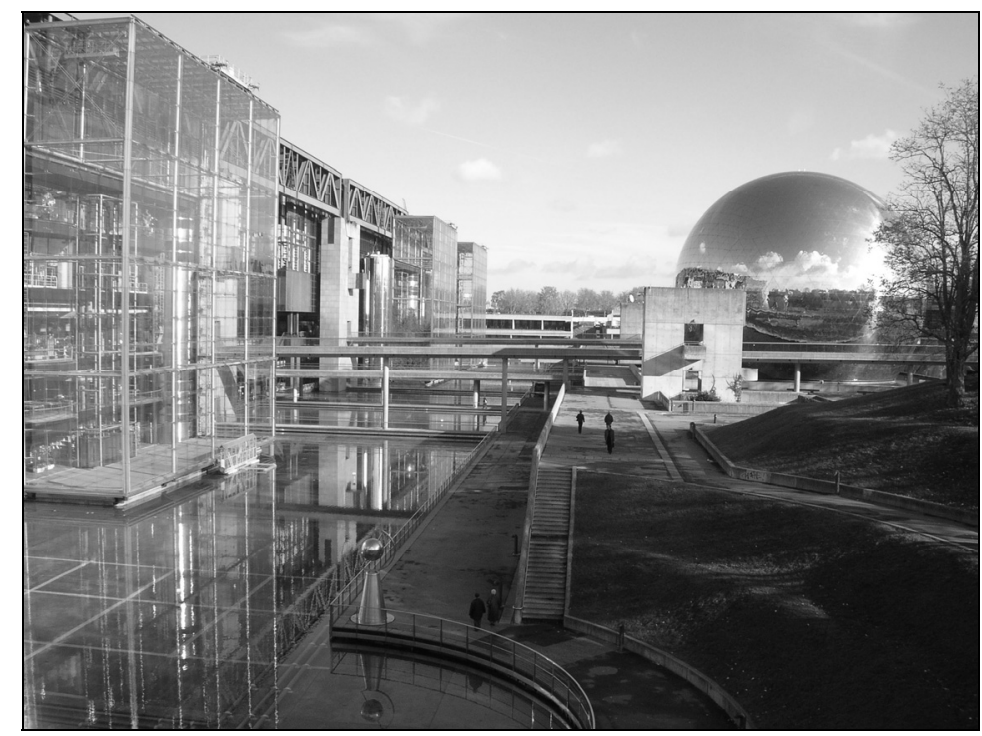

Fot. 1. Na miejscu dawnej rzeźni na przedmieściu Paryża w La Vilette wybudowano w 1986 r.

Cité des Sciences et de l'Industrie o fantastycznym programie ${ }^{*}$ (Fot. S. J. Kozłowski)

* Miasteczko Nauki i Przemysłu jest jednym z najczęściej odwiedzanych miejsc w Paryżu (3,5 mln zwiedzających rocznie), gdzie godzinami przebywają całe rodziny z dziećmi. Można tam niemal wszystkiego dotknąć (poza piraniami) i doświadczyć, począwszy od zjawisk fizycznych ze sfery złudzeń optycznych, magnetyzmu, elektryczności po wnętrza kapsuł dla załogi pojazdów kosmicznych. W pewnym stopniu otwarte w 2010 r. Centrum Nauki „Kopernik” w Warszawie wzorowane jest na Cité des Sciences et de l'Industrie. 
W tym okresie zaczęły funkcjonować Programowane Operacje Poprawy Mieszkalnictwa (OPAH), polegające na umowach między stroną rządową a samorządem miejskim, które obejmowały szerszy program odnowy: remonty mieszkań, rozwiązywanie spraw społecznych, rozwój gospodarczy i poprawę przestrzeni publicznych ${ }^{25}$. Kolejne umowy zawierają samorządy z tzw. operatorami, którzy są odpowiedzialni za projekt i realizację programów rewitalizacji. Programy te początkowo finansowane były na szczeblu krajowym ze specjalnego Funduszu Zagospodarowania Przestrzeni Miejskiej, później włączonego do ogólnej subwencji dla samorządów.

W latach osiemdziesiątych system ten został rozwinięty - powstał nowy typ Operacji Programowanych, w których obowiązywały bardziej złożone procedury, począwszy od diagnozy stanu zabudowy, analizy problemów społecznych, rozeznania potrzeb $\mathrm{w}$ sferze usług i handlu, wstępnego preliminarza kosztów całej rewitalizacji itp. Programami objęto zarówno remonty mieszkań wynajmowanych, jak i mieszkań zajmowanych przez ich właścicieli. Napotykano oczywiście szereg trudności, np. zbyt małą zdolność kredytową mieszkańców, rozdrobnienie gruntów miejskich itp. Liczba wyremontowanych mieszkań dzięki tym programom sięga 4 mln w okresie 15 lat.

Kolejny okres to prezydentura F. Mitteranda (1981-1995), wybranego na to stanowisko $\mathrm{w}$ dużej mierze dzięki hasłom socjalistycznym. Zmiana dotychczasowej polityki, polegającej $\mathrm{m}$. in. na decentralizacji, prowadzi do umów między władzą centralną a regionami, departamentami i gminami. Zwiększony nacisk położony został na problemy ludności zagrożonej wykluczeniem społecznym. Utworzono Strefy Ochrony Dziedzictwa Architektonicznego i Urbanistycznego, rozszerzone z czasem o problematykę ochrony krajobrazu miejskiego. Kompetencje $\mathrm{w}$ tych sferach scedowane zostały na niższe szczeble administracji, pozostawiając dla szczebla rządowego ochronę obiektów figurujących $\mathrm{w}$ rejestrze zabytków.

\subsubsection{Ewolucja polityki rewitalizacji w ostatnim 20-leciu}

Lata 1989-2000 charakteryzują się odejściem od polityki bezpośredniego sterowania i finansowania programów dotyczących miast na korzyść stymulowania, inspirowania i koordynowania. W dłuższym czasie nie przynosi to należytych rezultatów, choć $\mathrm{w}$ dalszym ciagu wspomagane są rodziny w trudnej sytuacji, mające trudności w dostępie lub w utrzymaniu samodzielnego mieszkania. Daż̇y się do dalszego różnicowania oferty mieszkań na rynku, co pozwala wielu rodzinom dopasować wybór mieszkania do ich możliwości i preferencji.

${ }^{25}$ Umowy te przypominają kontrakty wojewódzkie, wprowadzone w Polsce ustawą z dnia 12 maja $2000 \mathrm{r}$. o zasadach wspierania rozwoju regionalnego. 
Państwo stara się też zapewnić właściwą infrastrukturę i rozmieszczenie usług w skali najmniejszych dzielnic, aby zapewnić wszystkim mieszkańcom łatwą dostępność przestrzenną do usług. Wprowadza się również program lepszej integracji wielkich osiedli mieszkaniowych i elementy ich humanizacji. Stymulowany jest także proces wykupu mieszkań poprzez pożyczki mieszkaniowe na preferencyjnych warunkach dla rodzin o dochodach poniżej pewnego pułapu. Akcentowany jest wzrost partycypacji społecznej - wprowadzane są różne instrumenty służące mobilizacji mieszkańców do działania, współuczestniczenia w procesie podejmowania decyzji. Jednocześnie Agencja ds. Poprawy Mieszkalnictwa dostaje uprawnienia do subwencjonowania remontów wszystkich prywatnych mieszkań wynajmowanych w budynkach starszych niż 15 lat (programy tego typu są, w przeciwieństwie do Polski, akceptowane społecznie). Agencji tej podlega ok. 1,3 mln mieszkań o obniżonym standardzie, a kolejne $2 \mathrm{mln}$ mieszkań to pustostany $(1992)^{26}$. W tym czasie wyburzono pierwsze wielkie bloki wybudowane według idei Le Corbusiere'a.

Od roku 1990 działa we Francji Ministerstwo ds. Miasta, którego głównym zadaniem była dotychczas kontynuacja polityki odnowy miast, w tym także jako koordynatora godzącego realizację różnych programów w ramach poszczególnych resortów na terenie miast. Od 1994 r. dysponowało własnym budżetem, a jego celem było m.in. łączenie różnorodnych funduszy rozproszonych $\mathrm{w}$ różnych ministerstwach $\mathrm{w}$ celu ich skoncentrowania na wybranej grupie miast, w których występowały problemy deprywacji. Wynikiem działania tego ministerstwa są coroczne pozycje wyodrębnione w ustawie budżetowej, przeznaczone na kompleksową odnowę wyznaczonych francuskich miast. Ponad 1300 dzielnic w tych miastach objęły umowy z ich zarządami, na które państwo przeznaczyło 5 mld franków (ok. 1 mld \$). Korzystają one z ulg podatkowych, preferencyjnych kredytów i premii.

W tym okresie utworzono też, podległy bezpośrednio premierowi, Międzyresortowy Komitet ds. Miast, koordynujący działania różnych resortów na terenie miast, programy rozwoju i rozdzielający fundusze na te cele. Instytucji tej nadano wysoką rangę. Jednocześnie rozszerzona została współpraca szczebla rządowego z samorządami lokalnymi, w tym m.in. poprzez umowy miejskie z wybranymi miastami borykającymi się z wieloma problemami. Dodać do tego należy tworzenie stref ekonomicznych, na ogół na obrzeżach miast (zones de l'industrie, zones d'activités, parcs d'activités). Ramieniem rządu w miastach stało się nowe stanowisko podprefekta, dzięki czemu zacieśniło się partnerstwo między rządem a samorządem lokalnym. Polityka rewitalizacji jest w ten sposób częścią ogólnej polityki rozwoju miast, programowaną na szczeblu centralnym. Jej realizacja jest jednak powierzona samorządom lokalnym.

${ }^{26}$ K. Skalski, Rewitalizacja we Francji, seria: Rewitalizacja Miast Polskich, t. 2., Kraków 2009, s. 43. 
Ciekawym instrumentem jest wprowadzenie ulgi podatkowej dla właścicieli budynków w Strefach Ochrony Dziedzictwa Architektonicznego w przypadku całkowitej ich renowacji. Obniżony do 5,5\% został podatek VAT za remont własnego lub socjalnego mieszkania lokatorskiego. Wprowadzony został ustawowy podatek od wolnych mieszkań, co zmobilizowało właścicieli pustych mieszkań do ich wynajmowania i wpłynęło na poszerzenie oferty mieszkaniowej, a co za tym idzie - obniżenie czynszów w niektórych aglomeracjach. W 1995 r. uchwalona została Ustawa o ukierunkowaniu zagospodarowania terenów, dająca prawo zwolnienia przedsiębiorców z niektórych obciążeń finansowych w tzw. strefach ponownej aktywizacji miasta. Powoduje to pewne wzmożenie inwestycji prywatnych w zaniedbanych dzielnicach miast.

W tym samym roku powstało Ministerstwo Zagospodarowania Przestrzennego, Miast i Integracji. Zamieszki w spokojnych dotychczas miastach skłoniły rząd do podjęcia szerszej inicjatywy, w tym poprzez propozycję stworzenia stref ekonomicznych i stref aktywizacji zawodowej, skierowanej do ludzi poniżej 25 lat. Dzięki 5-letnim umowom z lokalnymi przedsiębiorstwami publicznymi i wspólnotami ci młodzi ludzie mieli zagwarantowaną pracę i szkolenie zawodowe. Przyczyniło się to do poprawy ich sytuacji społecznej i finansowej w zaniedbanych dzielnicach wielu miast, co wpłynęło m. in. na zmniejszenie napięć społecznych i wzrost poziomu bezpieczeństwa.

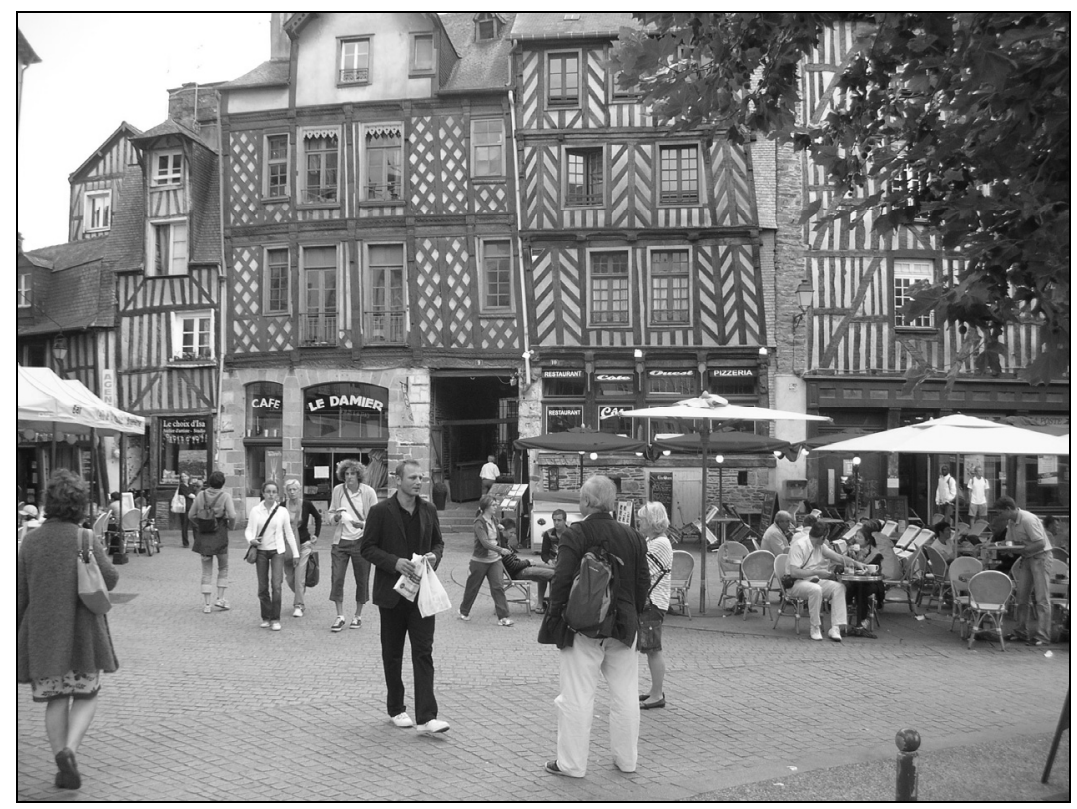

Fot. 2. Rennes - główne miasto Bretanii. Przestrzeń publiczna w zrewitalizowanej najstarszej części miasta (fot. S. J. Kozłowski) 
Ustawa z 2003 r. O ukierunkowaniu i programach na rzecz miast i odnowy miast świadczy o silniejszym niż dotychczas zaangażowaniu państwa na rzecz odnowy miast i uznaniu mieszkalnictwa jako głównego elementu rewitalizacji zdeprywowanych dzielnic. Dzielnice te to nie tylko peryferyjne wielkie osiedla mieszkaniowe, ale także podupadłe centralne dzielnice miast. Sytuację w miastach Francji pogarszał duży udział imigrantów, głównie z Afryki, którzy słabo się integruja $\mathrm{z}$ rdzennymi mieszkańcami wskutek słabej znajomości języka, niskiego poziomu wykształcenia, wysokiego poziomu bezrobocia, odmienności religijnej itp.

W ostatnim okresie coraz większy nacisk kładzie się na problemy społeczne w miastach, czego wyrazem jest zmiana dotychczasowych Kontraktów Miejskich na Kontrakty Miejskiej Spójności Społecznej (2007 r.), obejmujące wykazy projektów dla poszczególnych dzielnic, w których, obok mieszkalnictwa i rozwoju ekonomicznego, ujmowana jest problematyka środowiska życia, zatrudnienia, edukacji, zdrowia, przestępczości i prewencji oraz postaw obywatelskich ${ }^{27}$. Podobnie jak w Anglii, na podstawie odpowiednio dobranych wskaźników ekonomicznych i społecznych wyznaczono strefy wrażliwe w miastach (w liczbie 751). Było to możliwe dzięki bardzo dobrej statystyce, która pozwala na uchwycenie zróżnicowania struktur społecznych i gospodarczych dla małych jednostek sąsiedzkich w miastach.

Na szczeblu centralnym stworzono ostatnio we Francji dwa programy: Narodowy Program Odnowy Miast (PNRU) i Narodowy Program Spójności Społecznej oraz dwie agencje odpowiedzialne za ich realizację - Narodową Agencję dla Odnowy Miast (ANRU, powstała w 2003 r.) i Narodową Agencję Spójności Społecznej i Równości Szans (ACSE). Ich pracę inspiruje, koordynuje i nadzoruje Delegatura Międzyresortowa dla Miast (DIV), której szefem jest premier lub minister ds. miast, dzięki czemu przypisuje się jej niezwykle ważną rolę. Delegatura ta wespół z ministrem ds. miasta opracowuje m.in. zmiany $\mathrm{w}$ prawie, co jest podstawą prawidłowego funkcjonowania miast ${ }^{28}$. Rozwija też system informacji statystycznej w skali tzw. jednostek sąsiedzkich miast, niezwykle przydatny przy wyborze obszarów przeznaczanych do rewitalizacji, a później do obiektywnej oceny zmian (ewaluacji) w trakcie realizacji tego procesu (dotyczy to m.in. zmian w sferze bezrobocia, edukacji, rozwoju ekonomicznego, bezpieczeństwa itp.). Mając przegląd i możliwość oceny skuteczności różnych projektów realizowanych przez samorządy w całym kraju, Delegatura upowszechnia dobre praktyki i nowatorskie inicjatywy, także poprzez wymianę doświadczeń na szczeblu krajowym i międzynarodowym.

\footnotetext{
${ }^{27}$ K. Skalski, Rewitalizacja..., s. 57.

${ }^{28} \mathrm{~W}$ Polsce już 18 lat trwają bezskuteczne próby uchwalenia ustawy o rewitalizacji, co dowodzi braku zainteresowania władz centralnych tym tematem.
} 
Aktualnie Narodowa Agencja dla Odnowy Miast, której głównym celem jest odnowa powojennych osiedli mieszkaniowych (w praktyce głównie budownictwa wielkopłytowego) ma za zadanie zrealizować ww. program rewitalizacji 530 dzielnic, na co przewidziano środki w wysokości 30 mld euro do 2013 r. Agencja ta podjęła uproszczenie procedur oraz ściślejszą koordynację działań i finansowania rewitalizacji miast, dzięki czemu może dysponować znacznymi funduszami publicznymi i prywatnymi. Łącznie agencja ta przeznacza na subwencjonowanie procesu rewitalizacji ponad $5 \mathrm{mld}$ euro rocznie, w tym ok. 4 mld z budżetu państwa. Należy tu podkreślić, że istnieje we Francji wyraźny podział zadań w sferze rewitalizacji zabudowy mieszkaniowej - wspomniana Narodowa Agencja dla Odnowy Miast (ANRU) zajmuje się powojenną zabudową osiedlową, natomiast stare zasoby mieszkaniowe są w gestii Krajowej Agencji ds. Poprawy Mieszkalnictwa (ANAH).

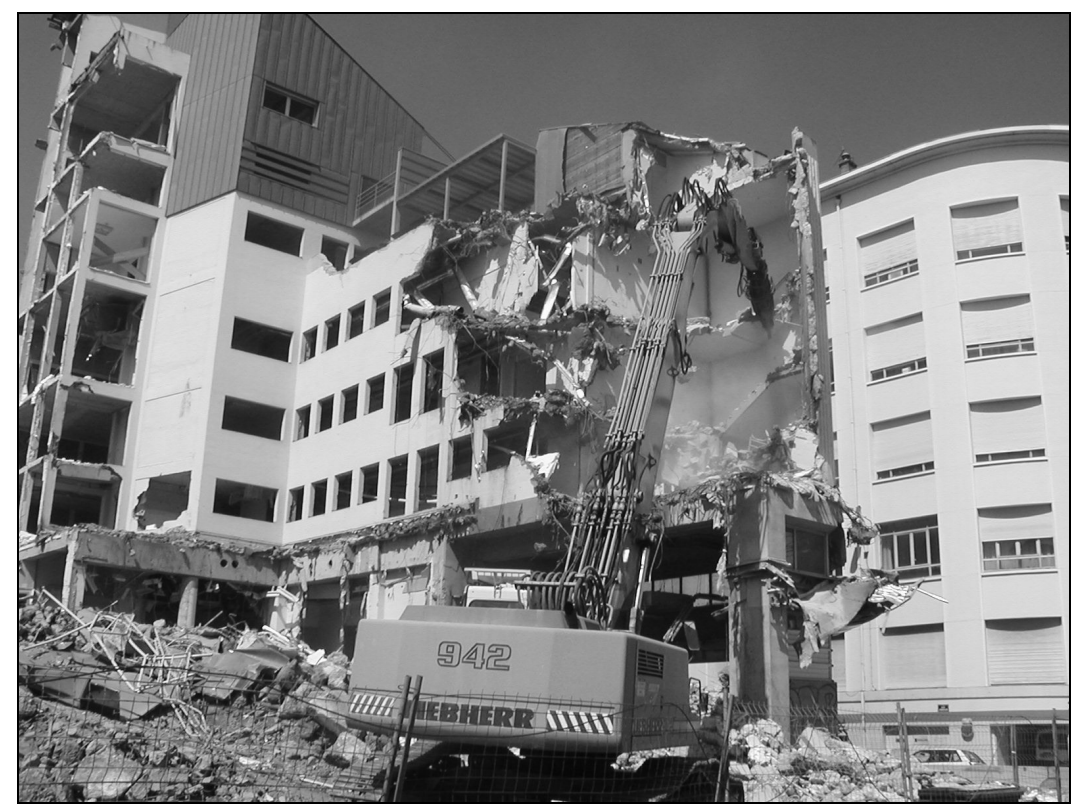

Fot. 3. Wyburzenia zabudowy osiedlowej w Lyonie, 2005 r. (fot. G. Węcławowicz)

Jedną z ważniejszych instytucji współpracujących w sferze rewitalizacji jest Kasa Depozytowo-Konsygnacyjna, pełniąca rolę ,kasjera” rządu francuskiego i finansująca najbardziej kosztowne inwestycje publiczne we Francji. Jej udział jest więc niezwykle istotny ${ }^{29}$. W dalszym ciagu funkcjonuje lokalny $1 \%$ podatek

${ }^{29}$ Kasa Depozytowo-Konsygnacyjna (Caisse des Dépôts et Consignations) zarządza depozytami ludności, kontami oszczędnościowo-emerytalnymi i różnymi chronionymi prawem funduszami prywatnymi. Administruje też inwestycjami i udziałami państwa w firmach prywatnych, 
od płac, który płacą przedsiębiorcy na fundusz mieszkaniowy, co pozwala na dofinansowanie poprawy warunków mieszkaniowych (w skali kraju wynosi on ok. $550 \mathrm{mln}$ euro rocznie).

Narodowy Program Odnowy Miast jest bardzo ambitny i zakłada na mocy ustawy z 2005 r. m.in. wyburzenie 250 tys. mieszkań, ich odtworzenie w sektorze publicznym, często poprzez dobudowę nowych budynków w osiedlach wielkopłytowych, oraz odnowę kolejnych 400 tys. mieszkań na wynajem w tym sektorze.

Aktualnie funkcjonuje wiele różnych instrumentów, których należyta koordynacja i połączone fundusze przynoszą poprawę warunków życia w zaniedbanych dzielnicach miast. W sferze społecznej jest to m.in. program wakacyjno-sportowy, dzięki któremu młodzież $\mathrm{w}$ takich dzielnicach ma organizowane wakacje lub całoroczne zajęcia sportowe. Propagowane jest zdrowe życie - tworzone są projekty na najniższym poziomie lokalnym dla zagrożonych wykluczeniem społecznym, dzięki czemu uzyskują oni dostęp do lekarzy, leków i wiedzy np. na temat zdrowego odżywiania. Tworzone są w takich dzielnicach setki interdyscyplinarnych zespołów, mających za zadanie poprawić wyniki nauczania i efekty wychowania młodzieży zagrożonej wykluczeniem społecznym. Wszystkie te działania należycie koordynowane i połączone z fizyczną odnową zaniedbanej zabudowy, poprawą komunikacji publicznej, pobudzaniem rozwoju gospodarczego w dzielnicach ,wrażliwych” powodują widoczny wzrost poziomu życia ich mieszkańców.

Choć polityka rewitalizacji miast ulegała ewolucji, jej cechą charakterystyczną było stałe i silne zaangażowanie władz centralnych $\mathrm{w}$ ten proces w całym niemal okresie powojennym. Dotyczy to zarówno tworzenia odpowiednich instytucji, jak i wsparcia finansowego. To zaangażowanie ma swoje źródła w idei francuskiego egalitaryzmu, co przejawia się m.in. w dążeniu do umożliwienia każdej rodzinie dostępu do odpowiadającego jej mieszkania.

Obok instytucji centralnych duża część zadań realizowana jest na szczeblu regionalnym i lokalnym, m.in. bardzo szerokie kompetencje obejmujące różne aspekty rozwoju gospodarczego mają Agencje Rozwoju Regionalnego. Niezależnie od nich funkcjonują w niektórych regionach Regionalne Agencje Polityki Gruntowej (EFP). Do gospodarki gruntami, szczególnie na terenach poprzemysłowych w miastach, przywiązuje się, podobnie jak w Anglii i w Niemczech, dużą wage ${ }^{30}$. Wynika to $\mathrm{w}$ dużej mierze $\mathrm{z}$ silnej deindustrializcji w tych krajach

inwestycjami typu private equity, inwestuje w ramach partnerstwa publiczno-prywatnego, co w istotny sposób zwiększa możliwości finansowania procesu rewitalizacji.

${ }^{30}$ Zupełnie odwrotnie niż w Polsce. Świadczy o tym uchwalenie, pod naciskiem lobby deweloperskiego, ustawy o odrolnieniu gruntów rolnych w miastach (uchwała z dn 19.12.2008 r. o zmianie ustawy o ochronie gruntów rolnych i leśnych - DzU nr 237, poz.1657), która nieuchronnie spowoduje wzmożenie chaotycznej i rozproszonej zabudowy peryferii miast na tzw. surowym korzeniu (ang. greenfields), co w oczywisty sposób zmniejsza szanse na właściwą 
i wielkich powierzchni terenów poprzemysłowych, które powinno się na terenie miast powtórnie zagospodarować. Przede wszystkim jest to jednak wyraz świadomej polityki państwa, którego władze dążą do ponownego zagospodarowania zdegradowanych i opuszczanych terenów w miastach, ograniczając jednocześnie przestrzenną ekspansję miast na tereny przyrodniczo czynne. Dzięki temu, że agencje te funkcjonują w ramach szerszej polityki miejskiej, koordynowanej na szczeblu centralnym, mają rzeczywisty wpływ na procesy rozwoju i odnowy na terenach opuszczonych przez przemysł. Regionalne Agencje Polityki Gruntowej stają się powoli operatorami rekultywacji zdegradowanych terenów, doprowadzając je do stanu, który umożliwia ich powtórne zagospodarowanie (np. stworzenie parków, budowę osiedli mieszkaniowych, centrów handlowych itp.) Dużą wagę przywiązuje się we Francji do takiego przekształcania zdegradowanych terenów poprzemysłowych, aby na nowo ukształtować estetyczny krajobraz miejski - co ma szczególne znaczenie na terenach pogórniczych (np. zagospodarowanie hałd). Jednocześnie dopuszczalne jest przygotowanie do zagospodarowania terenów rolnych przeznaczonych pod zabudowę, w rejonach o wyraźnym deficycie terenów budowlanych. W tych przypadkach agencja EFP wykupuje takie grunty i w porozumieniu z gminami odsprzedaje je pod nowe inwestycje gminie lub prywatnym inwestorom.

Wśród zadań, jakie agencje polityki gruntowej mają do wykonania, można wymienić: badania zanieczyszczenia gruntów i ich stabilności, stanu budynków, wyburzanie obiektów przewidzianych do rozbiórki, częściową likwidacją fundamentów, demontaż instalacji przemysłowych, zbiorników podziemnych, przenoszenie sieci infrastruktury, wywiezienie szkodliwych odpadów i recykling odpadów nieskażonych, niwelowanie terenu, zabezpieczenie budynków przeznaczonych do adaptacji, zabezpieczanie brzegów i skarp, renaturyzacja ${ }^{31}$, zachowanie istniejącej roślinności ${ }^{32}$. Agencje polityki gruntowej uczestniczą $\mathrm{w}$ różnym stopniu $\mathrm{w}$ realizacji programów rewitalizacji, $\mathrm{w}$ tym $\mathrm{np}$. $\mathrm{w}$ programach budowy nowych mieszkań $\mathrm{i}$ ich integracji $\mathrm{z}$ istniejącą zabudową (ten czynnik w Polsce jest często ignorowany), co sprzyja realizacji tzw. „mixu społecznego". Kolejnym przykładem jest współpraca przy zaadaptowaniu naturalnych walorów terenu na potrzeby parku, strefy rekreacji itp.

rewitalizację istniejącej zabudowy jako bardziej kłopotliwej dla inwestorów. Tracimy w ten sposób poważnego partnera - inwestora prywatnego, który odwróci się od zaniedbanych dzielnic miast polskich i będzie inwestował na łatwo dostępnych terenach niezabudowanych, co z kolei wymusi kosztowną rozbudowę infrastruktury miejskiej. Przykładem może być wielkie osiedle Wilanów na peryferiach Warszawy, gdzie deweloper nie dość, że nie zapewnił mieszkańcom ulicy dojazdowej w kierunku centrum, to jeszcze żądał od miasta wykupu terenu pod tę drogę po cenie kilkakrotnie wyższej niż go nabył!

${ }^{31}$ Por. program renaturyzacji łódzkich rzek (http://www.mojalodz.fora.pl/rzeki,261/sokolowka, 584.html).

${ }^{32}$ K. Skalski, Rewitalizacja ..., s. 193. 


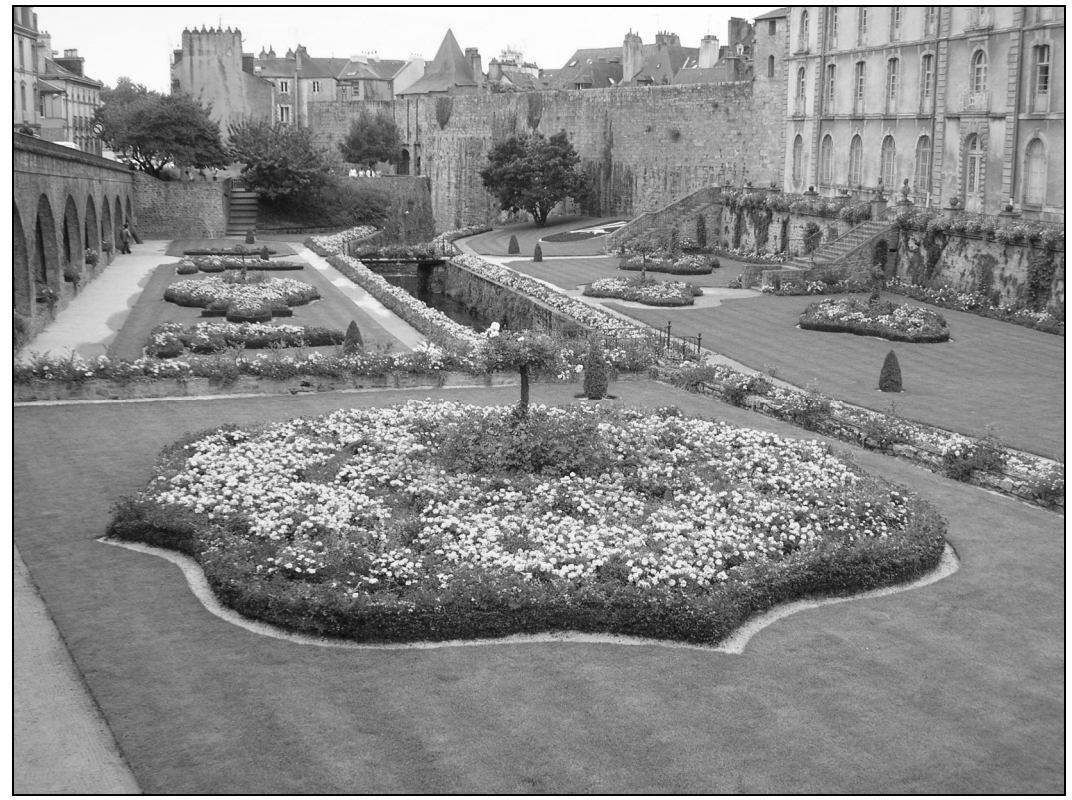

Fot. 4. Vannes (Bretania). Pięknie zadbane ogrody wzdłuż dawnych murów miejskich u stóp zamku de l'Hermine jako przykład zagospodarowania przestrzeni publicznej na rewitalizowanym terenie (fot. S. J. Kozłowski)

Wiadomo, że proces rewitalizacji musi trwać minimum 15 lat, a często sięga 30 lat $\mathrm{i}$ więcej. Tak długi okres $\mathrm{w}$ zestawieniu $\mathrm{z}$ kadencyjnością władz samorządowych i państwowych stwarza niebezpieczeństwo wypaczania pewnych idei wypracowanych na początku, a drugiej zaś strony może doprowadzić do zbyt pospiesznego zrealizowania pewnych zadań (w celu „wykazania się” władzy - często, aby zdążyć przed wyborami), co może prowadzić do pogorszenia jakości programu.

\subsubsection{Finansowanie}

Francuska polityka mieszkaniowa obejmuje nie tylko nowe budownictwo mieszkaniowe, ale dotyczy całości mieszkalnictwa. Skutkiem tego z różnych źródeł wspomagane są finansowo remonty budynków i mieszkań istniejących, co w połączeniu z działaniami mającymi na celu integrowanie nowego budownictwa mieszkaniowego z istniejącą tkanką miejską przynosi sukcesy. Dzięki takiej polityce (wspierania budowy i remontów mieszkań na wynajem, mieszkań właścicielskich, przeznaczonych dla rodzin o niskich dochodach, średnich dochodach, mieszkania socjalne, mieszkania zastępcze na czas remontu, włączania do programów odnowy właścicieli i lokatorów mieszkań itp.) zwięk- 
sza się zróżnicowanie oferty na rynku i łatwiej jest znaleźć mieszkanie odpowiadające finansowej pozycji i preferencjom lokalizacyjnym różnych grup społecznych. Wsparcie finansowe uzyskać można z wielu źródeł, zarówno ze szczebla lokalnego, regionalnego, jak i rządowego.

Jedną $\mathrm{z}$ takich form wspomagania jest pomoc ze strony państwa na budowę i przystosowanie mieszkań w sektorze uspołecznionym, o czynszu niewygórowanym, a także mieszkań socjalnych dla rodzin o niskich dochodach. Przed 1995 r. stosowany był kredyt ułatwiający nabycie prawa własności mieszkania przez rodziny o niskich dochodach, później wprowadzony został na ten cel kredyt nieoprocentowany. Progi dochodów zostały tak ustawione, że ponad połowa rodzin we Francji może się ubiegać o taką formę wsparcia. Mechanizm jest taki, że wartość „utraconych” odsetek, skutkiem zerowego oprocentowania takich kredytów, rekompensowana jest bankom przez rząd.

W wyniku umowy pomiędzy stroną rządową a instytucjami finansowymi, udzielane są też kredyty o obniżonej stopie oprocentowania, wprowadzono również umowy, które ograniczają wysokość czynszów w wyniku remontu kamienicy i mieszkań. Przyznawany jest indywidualny zasiłek mieszkaniowy dla lokatorów o niskich dochodach. Ma to duże znaczenie podczas rewitalizacji, gdyż system ten pozwala pozostać mieszkańcom w dotychczasowych lokalach pomimo podwyższonego czynszu w wyniku modernizacji i podniesienia ich standardu. Ponadto właścicielom mieszkań o niskich dochodach przyznawane są subwencje za poprawienie warunków mieszkaniowych. Na obszarach rewitalizacji stawki tych subwencji są szczególnie wysokie.

Istnieje też od 1993 r. gwarancja kredytowa państwa dla kredytobiorców, którzy mogą mieć problem ze spłatą kredytu na zakup mieszkania - kolejne raty są wtedy spłacane z funduszy publicznych (dotyczy to osób o dochodach niższych od wyznaczonego limitu), co nie oznacza, że tacy kredytobiorcy mogą zaprzestać dalszego spłacania kredytu - ściaggane są wtedy odpowiednio niższe raty.

Niektóre mieszkania lokatorskie mogą korzystać z dodatków mieszkaniowych, a inwestorzy i właściciele $\mathrm{z}$ ulg podatkowych - dzięki temu na wrażliwych terenach $\mathrm{w}$ miastach możliwe jest $\mathrm{w}$ dużym stopniu zachowanie składu społecznego sprzed rewitalizacji. Francuski system pomocy mieszkaniowej dla rodzin oparty jest na tabelach dochodów. Dodatki mieszkaniowe w różnej wysokości przyznawane są na podstawie stosunku dochodów rodziny do jej wydatków na mieszkanie. Szacuje się, że w końcu lat dziewięćdziesiątych korzystało z nich ponad 6 mln osób.

Kolejne rządy Francji modyfikują, w zależności od zmieniających się okoliczności, swoją politykę wobec mieszkań i mieszkańców, korzystając z bogatej palety instrumentów, których oddziaływanie często jest już sprawdzone. Na obszarach rewitalizowanych oprócz różnorodnych kredytów, ulg i premii za remont czy ocieplanie budynków, stosowane są montaże finansowe funduszy 
gmin (zasilanych przez budżet państwa na te cele) łączonych z subwencjami regionalnymi. Pomocny w tym układzie jest podatek, jaki płacą przedsiębiorcy $(1 \%)$ od płac, który przeznaczany jest na fundusz mieszkaniowy ${ }^{33}$. Do tego dochodzi obniżony do 5,5\% podatek VAT od budowy nowych mieszkań o umiarkowanym czynszu i odtwarzanych w wyniku wyburzeń. Przyznawana jest też (pod pewnymi warunkami) pomoc na zakup terenu, w miejscach, gdzie jest on szczególnie drogi - jednym $\mathrm{z}$ warunków jest finansowy udział lokalnego samorządu.

Do roku 1998 wypłacane były subwencje dla mieszkań lokatorskich w wysokości 20\% kosztu robót remontowych, do pewnej maksymalnej kwoty ${ }^{34}$. Później wprowadzono m.in. obniżoną do 5,5\% stawkę podatku VAT dla remontów w mieszkaniach socjalnych i lokatorskich o umiarkowanych czynszach, połączoną z niższą niż uprzednio subwencją (obniżoną z 20\% do $10 \%$ ).

Wieloletnie doświadczenia Francji w sterowaniu i finansowaniu mieszkalnictwa doprowadziły m.in. do prób oszacowania kosztów całkowitych zamierzonej rewitalizacji. Dotyczy to zarówno stref poprzemysłowych, jak i mieszkaniowych. Konieczność przeprowadzenia kosztownych robót przystosowujących dany teren dla nowych inwestycji stawia wiele przedsięwzięć pod znakiem zapytania. Właściciel nie chce często takich prac podjąć, a władze publiczne czy ich agendy muszą uprzednio określić koszt likwidacji skomplikowanych instalacji przemysłowych, wyburzania nietypowych obiektów i oczyszczenia skażonego chemicznie terenu. Koszty te często przewyższają cenę, jaką można po tych pracach przygotowawczych uzyskać ze sprzedaży takiego gruntu. Rodzi to kolejny problem: jak powinny być rozłożone te koszty pomiędzy pierwotnego właściciela (który często nie może uwierzyć, że jego teren ma „wartość ujemną") $)^{35}$, władze publiczne, przyszłego dewelopera i ewentualnie mieszkańców. Sytuacja jest gorsza, gdy teren jest pozbawiony prawa zabudowy. Właściciele często blokuja proces odnowy, nie dysponując funduszami dla dostosowania swojego terenu do nowych inwestycji i naciskają na władze w celu uzyskania pomocy finansowej. Czasem okazuje się, że nowe użytkowanie danego terenu nie będzie przynosić dochodów, które pokryłyby wydatki poniesione na jego przystosowanie. Ważna jest $\mathrm{w}$ tej sytuacji możliwość określenia wszelkich kosztów i ich zbilansowania z przyszłymi dochodami, także po to, aby nakłady na rewitalizację można było oszacować w skali regionu i kraju ${ }^{36}$. Oczywiście koszty te często rosną np. przez nagminne niemal opóźnianie rozpoczęcia

\footnotetext{
${ }^{33}$ Obecnie podatek ten płacą przedsiębiorcy zatrudniający powyżej 20 pracowników, co dotyczy 11 mln ludzi.

${ }^{34}$ Rozwiązanie to przypomina stosowaną w Polsce w latach 90. dużą ulgę budowlaną.

${ }^{35}$ Przypomina to dziedziczenie spadku obciążonego długami, które spadkobierca musi spłacić.

${ }^{36}$ We Francji już w latach 70. stworzono matematyczny model, dzięki któremu nawet w trakcie posiedzenia rządu można było oszacować wpływ na dochody budżetowe propozycji wprowadzenia różnych ulg podatkowych, zmian zasiłków czy stawki podatku VAT.
} 
i wydłużanie się procesu rewitalizacji z powodów nieprzewidzianych (sporów prawnych, finansowych, opóźnienia i niemożności spłaty kredytów itp.).

Dzięki stworzeniu takich instytucji jak Delegatura Międzyresortowa dla Miast, które opracowują i koordynują politykę miejską we Francji, a w jej ramach programy rewitalizacji, możliwe jest także dość dokładne określenie nakładów na te działania $\mathrm{w}$ miastach. Nakłady te są rozproszone w różnych resortach (spraw wewnętrznych, sprawiedliwości, sportu, kultury, edukacji, infrastruktury). Nie są one małe: tylko na odnowę fizyczną miast na lata 20042008 szacowane były na kwote $30 \mathrm{mld}$ euro (w tym wyburzenia, budowa nowych obiektów, remonty i zagospodarowanie przestrzeni). Jest oczywiste, że gminy nie są $\mathrm{w}$ stanie udźwignąc takich wydatków, pomimo subwencji rządowych, a ich udział w bieżących kosztach rewitalizacji szacuje się na ok. 11\%. Zakładano, że udział departamentów i regionów będzie znaczący, jednak w ostatnich latach wyniósł on odpowiednio niespełna 4\% i nieco ponad 5\%. W tej sytuacji główny ciężar rewitalizacji fizycznej w ramach Narodowego Programu Odnowy Miast spoczywa na barkach państwowej Narodowej Agencji Odnowy Miast - w ok. 32\%, oraz na inwestorach wynajmujących mieszkania w sektorze publicznym (ok. 42\%).

Niezwykle istotna jest we Francji rola tzw. operatorów rewitalizacji, czyli organizacji, instytucji czy firm, które zdolne są prowadzić proces rewitalizacji przejmując na siebie rolę podobną do „inwestora zastępczego”, który organizuje i koordynuje cały proces. Zespół taki powinien się składać ze specjalistów wielu dziedzin: urbanistów, architektów, menedżerów, specjalistów od nieruchomości, mieszkalnictwa, własności gruntów, konserwatorów zabytków, socjologów, ludzi obdarzonych talentem negocjacyjnym (co jest szczególnie ważne podczas rozmów z mieszkańcami na temat programu rewitalizacji w ramach partycypacji społecznej, czy konieczności czasowych i definitywnych przeprowadzek). Jedną z takich organizacji jest pozarządowy Ruch Stowarzyszeń PACT-ARIM ${ }^{37}$. Zdaniem K. Skalskiego, który kilkanaście lat spędził we Francji, pracując przy różnych programach odnowy miast, formuła 40-letniego funkcjonowania tego ruchu nadaje się do przeniesienia na grunt Polski. Jest to organizacja typu non profit, która poszukuje partnerów do współpracy z gminą wśród prywatnych przedsiębiorstw i właścicieli budynków. Stara się ułatwić im działanie poprzez przygotowanie biznesplanów, wyszukiwanie źródeł finansowania, propagowanie idei remontów, pomoc przy przeprowadzkach, ułatwianie rozwoju lokalnego handlu i rzemiosła itp.

${ }^{37} \mathrm{~W}$ Polsce dopiero rozpoczął się proces kształcenia fachowców w tej dziedzinie np. w Collegium Polonicum w Słubicach, będącą wspólną placówką Uniwersytetu im. A. Mickiewicza w Poznaniu i Uniwersytetu Europejskiego Viadrina we Frankfurcie nad Odrą (UEV). Namiastką kształcenia w tym kierunku są programy studiów planowania przestrzennego na niektórych uczelniach. 
Francja, wykorzystując swoje doświadczenia, była jednym z głównych inicjatorów europejskich programów rewitalizacji miast, w tym także programu URBAN I i URBAN II. Szczególną rolę odgrywa tu Międzyresortowa Delegatura dla Miast, umocowana przy premierze Francji. Żałować należy, że Unia Europejska w obecnym okresie budżetowym znacznie ograniczyła liczbę tzw. Inicjatyw Wspólnotowych (z kilkunastu do zaledwie trzech) i w ten sposób wsparcie finansowo-inwestycyjne dla programów rewitalizacji zdegradowanych miast zostało praktycznie zlikwidowane. Jest to tym bardziej zaskakujące, że programy te doprowadziły do znakomitych rezultatów i uzyskały wręcz entuzjastyczne oceny unijnych ekspertów. W obecnym okresie budżetowym 2007-2013 UE wspiera procesy rewitalizacji jedynie poprzez wymianę doświadczeń, transfer wiedzy i propagowanie dobrych rozwiązań np. przez programy URBACT i JASPER ${ }^{38}$. Generalnie aktualna polityka Unii Europejskiej nakierowana jest raczej na uzupełnienie polityki rewitalizacji zabudowy (która jest domeną każdego państwa członkowskiego) działaniami w sferze społecznej i ekonomicznej.

Zaprzestanie przez Unię Europejską wspomagania finansowego rewitalizacji miast w okresie 2007-2013 nie wpłynęło we Francji znacząco na ograniczenie działań w tym zakresie. W dalszym ciągu jest tam widoczne silne zaangażowanie państwa zarówno w sferze instytucjonalnej, jak i finansowej.

W odróżnieniu od Polski, polityka rewitalizacji jest we Francji nie tylko od kilkudziesięciu lat realizowana, ale przebiega $\mathrm{w}$ ramach ogólnej polityki rozwoju miast. Niestety w Polsce nie mamy nawet instytucji, które ten rozwój mogłyby planować, koordynować i wspierać finansowo. Podobnie jak nie mamy w Polsce instytucji na szczeblu centralnym, które zajmowałyby się całokształtem polityki mieszkaniowej. Brak spójnej polityki miejskiej i mieszkaniowej ma bardzo negatywny wpływ na wysiłki samorządów i innych organizacji próbujących w sposób skuteczny prowadzić rewitalizację najbardziej zaniedbanych części miast. Problem ten dotyczy w szczególności zdegradowanych obszarów śródmiejskich, w których znaczna część zabudowy składa się z budynków mieszkalnych. „Niewidzialna ręka rynku” także nie przyczyniła się do zlikwidowania problemów degradacji wielu dzielnic miast nawet $\mathrm{w}$ najbogatszych państwach świata, łącznie z USA i bogatymi krajami UE.

${ }^{38}$ W latach 2007-2013 jedynie 3\% funduszy w ramach Regionalnego Programu Operacyjnego można w Polsce przeznaczyć na remont budynków mieszkalnych, pod warunkiem spełnienia szeregu warunków. Pewne fundusze można ponadto przeznaczać na cele rewitalizacyjne w ramach jednego z trzech głównych celów polityki spójności, a mianowicie celu 2: Konkurencyjność regionalna i zatrudnienie (K. Skalski, Rewitalizacja..., s. 88-89). Niezależnie od tego istnieją możliwości sfinansowania niektórych działań w ramach rewitalizacji z innych programów unijnych, np. z Programu Operacyjnego Kapitał Ludzki - w sferze walki z bezrobociem czy podwyższania kwalifikacji. Dlatego tak ważna jest znajomość funkcjonowania funduszy unijnych i działalność operatorów rewitalizacji, których zadaniem jest m.in. wyszukiwanie, koordynacja i montaż finansowy różnych źródeł zasilania procesu rewitalizacji. 


\subsection{Wielka Brytania}

\subsubsection{Początki i ewolucja programów rewitalizacji}

W Wielkiej Brytanii od dawna władze wszystkich szczebli zdają sobie sprawę, że polityka wobec miast i planowanie przestrzenne są jednym z kluczowych elementów rozwoju gospodarczego. W polityce miejskiej jedną z naczelnych zasad stanowi ograniczanie przestrzennej ekspansji miast na tereny sąsiednie. Służy temu m.in. system prawnie chronionych tzw. green belts, czyli zielonych pasów otaczających miasta. Pasy te składają się z lasów, łąk, wrzosowisk itp. i stanowią autentyczną barierę dla nowej zabudowy. Nie mając alternatywy, deweloperzy poszukujący lokalizacji pod zabudowę mieszkaniowa, biurową czy magazynową zmuszeni są do lokowania swoich inwestycji na terenach już zainwestowanych, najczęściej uzbrojonych (tzw. brown fields). Dzięki temu uzyskuje się podwójnie korzystny efekt: deweloperzy często skupiają swoją działalność na terenach podupadających i zdewastowanych, co jednocześnie wspomaga procesy rewitalizacji fizycznej, a $z$ drugiej strony ograniczany jest proces suburbanizacji na terenach przylegających do miast. W efekcie miasta stają się bardziej zwarte, zgodnie z zasadą tzw. compact city, zachowując na swoim zapleczu zielone tereny otwarte o naturalnym krajobrazie, sprzyjające wszelkim formom rekreacji.

Porównując te tendencje z polityką, a raczej brakiem polityki miejskiej w Polsce, łatwo stwierdzimy, że decyzje władzy państwowej prowadzą w dokładnie odwrotnym kierunku. Uchwalona w 2008 r. ustawa o odrolnieniu gruntów rolnych i leśnych $\mathrm{w}$ granicach miast spowoduje szybką ekspansję zabudowy na tereny zielone $\mathrm{w}$ miastach, gdyż deweloperzy zawsze wybiorą teren wolny i niezabudowany (chociaż nieuzbrojony), a pomijać będą obszary w strefach zabudowy miejskiej, które wymagają większej staranności, i których ponowna zabudowa jest bardziej kosztowna ${ }^{39}$. Traci się tym samym bardzo ważnego partnera w procesie rewitalizacji, gdyż, jak wskazują doświadczenia brytyjskie, inwestycje prywatnych firm na terenach przeznaczonych do rewitalizacji były bardzo znaczące. W tej sytuacji miasta polskie skazane będą $\mathrm{w}$ procesach rewitalizacji na ograniczone inwestycje z funduszy publicznych.

Miasta brytyjskie stosunkowo najwcześniej doznały kryzysu wynikającego ze splotu wielu czynników. Krótko po II wojnie światowej zaczęły tracić ludność w wyniku tzw. II-go przejścia demograficznego i odpływu wielu mieszkańców na tereny podmiejskie, wyludniały się centra miast m.in. na skutek polityki (zgodnej z Kartą Ateńską) budowy nowych osiedli na ich peryferiach.

${ }^{39}$ Ustawa z 19.12.2008 r. o zmianie ustawy o ochronie gruntów rolnych i leśnych (DzU nr 237, poz. 1657), http:/www.legeo.pl/prawo/ustawa-z-dnia-19-grudnia-2008-r-o-zmianie-ustawy-o-ochronie-gruntow-rolnych-i-lesnych/metryka/?on= 
Wyraźnie zmniejszała się liczba miejsc pracy w przemyśle ciężkim i włókienniczym. Robotnicy likwidowanych fabryk, pracujący w systemie fordowskim, z bardzo wąskim zakresem umiejętności, mieli trudności ze zdobyciem nowej pracy. W wielu brytyjskich portach zamierał ruch, gdyż coraz większe, nowoczesne statki, często kontenerowe, nie mogły być obsługiwane w starych dokach. W takich robotniczych dzielnicach pozostawały jedynie grupy najsłabsze ekonomicznie, co pogłębiało ich kryzys, a polityka banków z obawy przed stratami finansowymi nie pozwalała na udzielanie kredytów w celu modernizacji dewastowanej zabudowy. Kręte i wąskie ulice miast były przeszkodą dla rozwoju masowej komunikacji samochodowej, a to sprzyjało tworzeniu nowych centrów handlowych, w tym hipermarketów, na obrzeżach miast, co powodowało kryzys dzielnic śródmiejskich, w których stopniowo zaczęły dominować uboższe grupy społeczne.

Jednocześnie w Anglii, kraju, w którym rewolucja przemysłowa miała miejsce najwcześniej, istniała siłą rzeczy najstarsza zabudowa przemysłowo-magazynowa oraz towarzysząca jej zabudowa mieszkaniowa dla robotników, toteż proces dekapitalizacji tej substancji ujawnił się najwcześniej. Już w latach trzydziestych zaczęto wyburzać i modernizować najstarsze dzielnice mieszkaniowe, jednak te pierwsze próby nie wykraczały poza przebudowę fizyczna. W latach sześćdziesiatych ta polityka została uzupełniona o programy edukacyjne i pomocy społecznej, nie przyniosły one jednak widocznych rezultatów, gdyż nie ingerowały w źródła narastających problemów, leżące poza centrami miast.

Dopiero w latach osiemdziesiątych pod rządami Margaret Thatcher zaczęto wprowadzać elementy poprawiające gospodarcze podstawy funkcjonowania podupadających części miast, głównie poprzez rozwój działalności usługowych. Jednocześnie promowany był sektor prywatny w działaniach rewitalizacyjnych, a nawet stosowanie partnerstwa publiczno-prywatnego było warunkiem otrzymania wsparcia finansowego ze strony rządu. Powołano wówczas finansowane przez rząd (w formie grantów) korporacje rozwoju miast (UDC), które miały za zadanie zakup i przygotowanie pod nowe inwestycje terenów zdegradowanych, łącznie $\mathrm{z}$ wyburzeniami i rekultywacją zanieczyszczonych przez przemysł gruntów, ich uzbrojeniem i wspólne $\mathrm{z}$ inwestorami planowanie nowych przedsięwzięć. Korporacje te pozyskiwały kolejne fundusze na dalszą działalność m.in. ze sprzedaży oczyszczonych i przygotowanych pod inwestycje terenów, a także mogły brać na te działania pożyczki z banków.

Porównując te rozwiązania $\mathrm{z}$ warunkami polskimi, łatwo stwierdzimy zasadnicze różnice: partnerstwo publiczno-prywatne praktycznie w Polsce do roku 2009 nie funkcjonowało, a wyjątkowa podejrzliwość polskiego społeczeństwa i niektórych instytucji kontrolnych powoduje, że w dalszym ciągu obserwuje się duże opory władz samorządowych przed łączeniem kapitału publicznego z prywatnym. Izby obrachunkowe niektórych województw nie pozwalają np. na dofinansowanie remontów zabytkowych kamienic z funduszy gminnych. 
Jednocześnie w celu przyciagania nowych inwestycji stworzono system podobny do polskich specjalnych stref ekonomicznych, który umożliwił rozwój gospodarczy dzielnic zagrożonych upadkiem.

Silny akcent położony na ekonomiczną stronę funkcjonowania terenów zdegradowanych $\mathrm{w}$ miastach przyniósł $\mathrm{z}$ pewnością postęp $\mathrm{w}$ stosunku do poprzednich prób rewitalizacji, jednak ocenia się, że podniesienie standardu zrewitalizowanych obiektów, wprowadzenie dużej ilości nowych miejsc pracy i poprawa przestrzeni publicznych nie przyniosły oczekiwanych zmian społecznych, gdyż działania te ignorowały potrzeby dotychczasowych mieszkańców tych terenów (odnosi się to m.in. do rewitalizacji słynnych doków londyńskich).

Cechą charakterystyczną rozwiązań brytyjskich jest tworzenie wielu instytucji i programów, i nieustanne ich zmiany dokonywane w trakcie funkcjonowania kolejnych programów. Dodać do tego należy mnogość form i sposobów finansowania tych programów oraz silny nacisk na prowadzenie procesów rewitalizacyjnych w sposób partnerski, tzn. poprzez tworzenie konsorcjów różnorodnych instytucji, firm i organizacji oraz grup mieszkańców. Silny nacisk na szczeblu krajowym kładziono na pozyskiwanie prywatnych inwestorów, którzy, realizując swoje komercyjne cele, wspomagali proces rewitalizacji finansowany $\mathrm{z}$ funduszy publicznych. Szczególną formą takiego partnerstwa jest często partnerstwo publiczno-prywatne, polegające na łączeniu środków finansowych z wielu źródeł publicznych i prywatnych. W wielu programach takie partnerstwo było warunkiem uzyskania wsparcia ze strony budżetu państwa.

Zamieszanie i rozproszenie środków wynikające z tej różnorodności powodowało trudności samorządów poszczególnych miast $\mathrm{w}$ dostosowaniu się do takiego systemu. W latach dziewięćdziesiątych wprowadzono system konkursów na projekty rewitalizacji i tylko najwyżej oceniane mogły liczyć na wsparcie finansowe. Promowano w ten sposób najbardziej przedsiębiorcze władze i lokalnych przedsiębiorców na danym terenie, jednak system ten stawiał na straconej pozycji te najsłabsze, silnie zdegradowane fragmenty miast, które często reprezentowane są przez słabo przygotowanych urzędników ${ }^{40}$. Obrońcy tego systemu twierdza, że blisko 20\% środków publicznych kierowanych jest do najbardziej zdegradowanych obszarów miejskich, a ponieważ rewitalizacja dotyczy miast, to kompetencje ich władz w całej Wielkiej Brytanii są na odpowiednim poziomie.

Pozytywnym akcentem ówczesnych działań rewitalizacyjnych było promowanie objęcia tym procesem możliwie wielu problemów - fizycznego stanu zabudowy, podstaw dalszego rozwoju gospodarczego, rozwiązania trudnych spraw społecznych, problemów ochrony środowiska i komunikacji.

${ }^{40}$ Podobne zjawisko w innej skali obserwujemy w Polsce - najsłabsze gminy ubiegające się o fundusze unijne często stoją na straconej pozycji, gdyż nie są wystarczająco sprawne w konstruowaniu wniosków o dotacje. 
Istotne zmiany nastapiły po dojściu do władzy Partii Pracy w roku 1997, która zgodnie ze swoją tradycją położyła silny nacisk na zjawisko wykluczenia społecznego w miastach, przenosząc wiele uprawnień na szczebel lokalny. Polityka wobec miast uzyskała nowy impuls, dzięki poszukiwaniu przyczyn kryzysu miast brytyjskich i sposobów jego przezwyciężania. Popierana była koncepcja compact city, czyli miasta zwartego, z atrakcyjnymi ulicami handlowo-usługowymi w zasięgu dojścia pieszego i rozwojem komunikacji publicznej. Ważną częścią tej strategii było wspieranie przebudowy miejskich terenów zdegradowanych przy jednoczesnym hamowaniu rozprzestrzeniania się miast. Uzyskano przy tym szereg korzyści, takich jak poprawa wyglądu miast, większe ich nasycenie placówkami handlowymi i usługowymi, uchronione zostały tereny czynne przyrodniczo przed ekspansją budownictwa w wyniku suburbanizacji i zahamowano narastanie problemów komunikacyjnych z nadmiernie rozrastającymi się osiedlami podmiejskimi.

Nowe formy przybrało zwalczanie długotrwałego bezrobocia, prowadzącego do wykluczenia społecznego. Ludzi, którzy już dawno stracili wiare w zdobycie jakiejkolwiek pracy, zaczęto przywracać do życia społecznego ${ }^{41}$. Tych, którzy nie pracowali od 20 lat i byli klientami wszystkich możliwych instytucji pomocowych, zaczęły przywracać do życia społecznego firmy prywatne. W 10 lat po rozpoczęciu tego programu w Wielkiej Brytanii pracowało już 70\% zdolnych do pracy (w Polsce aktualnie pracuje jedynie 46\%). Wzrosło znacznie zaufanie do prywatnych firm, które podjęły trud skłaniania uporczywie bezrobotnych do szukania pracy i robily to bardzo skutecznie. Zadaniem specjalistów było m.in. nauczyć swoich podopiecznych odpowiednio mówić, pisać, zachowywać się, nierzadko nabrać pewności siebie, aby rozmawiać z potencjalnym pracodawcą. Niektórym „mieszkającym pod mostem” trzeba było wynajać mieszkanie, przypomnieć zasady utrzymania higieny osobistej, nauczyć obsługi komputera. Pół roku takiego przygotowywania powinno wystarczyć na znalezienie pracy. Wtedy dopiero osobisty doradca (firma prywatna) otrzymuje wynagrodzenie, a skuteczność najlepszych na rynku przekracza $70 \%$ przywróconych do życia w społeczeństwie. Siłą rzeczy największa koncentracja takich wykluczonych występuje na terenach zdegradowanych $\mathrm{w}$ miastach, które obejmowane są programami rewitalizacji.

Rewitalizacja zabudowy mieszkaniowej była uzależniana od lokalnych warunków. Począwszy od lat siedemdziesiątych na obszarach kryzysowych podejmowano różne typy działań. Część mieszkań odnawiali sami właściciele, przy finansowym udziale władz lokalnych, co jak wspomniano wyżej, w Polsce napotyka sprzeciw władz finansowych kontrolujących wydatki gmin. Tak zwane podejście socjalne obejmowało z kolei odnowę mieszkań przez

\footnotetext{
${ }^{41}$ Por. art. E. Winnickiej, Holownik osobisty, „Polityka” 2009, nr 18, s. 38.
} 
organizacje pozarządowe, a trzecim typem było wykupywanie obszarów zdegradowanych i ich odsprzedaż inwestorom prywatnym w celu podjęcia przez nich rewitalizacji ${ }^{42}$.

Na uwagę zasługuje jakość brytyjskiej statystyki, dzięki której można na terenie miast wydzielać obszary kryzysowe na podstawie wielu kryteriów. Dane statystyczne zbierane są dla tzw. jednostek sąsiedzkich i obejmują zagadnienia społeczne, środowiskowe, infrastrukturalne itp. Dzięki temu, na podstawie badań danych statystycznych, można obiektywnie wyodrębniać obszary wymagające wsparcia funduszami publicznymi. Między innymi jednym z warunków objęcia danego terenu programem rewitalizacji i wspomagania go środkami publicznymi było istnienie min. 30\% gospodarstw domowych korzystających z pomocy państwa.

Po roku 1989 brytyjski rząd położył znacznie silniejszy nacisk na partycypację społeczną. Niepowodzenia wielu form rewitalizacji w ciagu kilku dziesięcioleci doprowadziły władze do wniosku, że warunkiem ich powodzenia jest przywracanie więzi społecznych, prowadzenie konsultacji społecznych i zapewnienie jak najszerszego udziału lokalnej społeczności w formułowaniu programów przebudowy.

Od roku 2000 zaczęły funkcjonować dwa programy w sferze odnowy substancji mieszkaniowej. Jeden $\mathrm{z}$ nich ma zapewniać poprawę jakości życia poprzez wzrost zatrudnienia, walcząc z wykluczeniem społecznym, wspierając rozwój lokalny dzięki poprawie środowiska i infrastruktury technicznej. Drugi, poprzez wprowadzanie nowego budownictwa mieszkaniowego na tereny zdegradowane i wzrost atrakcyjności terenów mieszkaniowych ma przyciagać nowych mieszkańców do centrów miast.

\subsubsection{Wspólczesne instytucje i organizacje zarządzające rewitalizacją}

Obecnie procesy rewitalizacyjne prowadzone są w Wielkiej Brytanii przez wiele instytucji, agencji, firm prywatnych i organizacji pozarządowych ${ }^{43}$. Na szczeblu rządowym zaangażowane $\mathrm{w}$ tej sferze są dwa ministerstwa: Ministerstwo ds. Społeczności i Władz Lokalnych, które prowadzi politykę wobec miast, obejmującą mieszkalnictwo i planowanie przestrzenne, a także zajmuje się problemami wykluczenia społecznego oraz Ministerstwo Gospodarki, które prowadzi politykę rozwoju gospodarczego, zatrudnienia i rozwoju regionalnego.

Pierwsze $\mathrm{z}$ nich finansuje narodową agencję rewitalizacji (English Partnership), o budżecie sięgającym $700 \mathrm{mln}$ funtów w roku 2009 (ok. 60\% jej docho-

\footnotetext{
${ }^{42}$ Wg K. Gorczycy, Polityka mieszkaniowa w Wielkiej Brytanii, [w:] R. Guzik (red.), Rewitalizacja miast w Wielkiej Brytanii, seria: Rewitalizacja Miast Polskich, t. 1, IRM, Kraków 2009, s. 35.

${ }^{43}$ Szczegółowe omówienie ich statusu, budżetu itp. znajdzie czytelnik w: R. Guzik (red.), Rewitalizacja..., s. 44.
} 
dów stanowią zyski ze sprzedaży przygotowanych do zabudowy nieruchomości i innych działań komercyjnych). Do priorytetowych obszarów objętych pomocą należą m.in. najbardziej zdeprywowane obszary mieszkaniowe, tereny po zamkniętych kopalniach i tereny, na których działają Przedsiębiorstwa Rewitalizacji Miast (Urban Regeneration Companies).

Na terenie Anglii i Walii funkcjonuje ponad 20 różnych programów, które nie mają postaci instytucjonalnej, np. Hospital Sites Programme, zajmujący się zagospodarowaniem obiektów i terenów poszpitalnych na cele mieszkaniowe lub komercyjne. Jest ich blisko $100^{44}$.

Jednym z programów pilotowanych przez English Partnership jest Land Sales Programme, dysponujący aktualnie ok. 6 tys. ha pod nowe inwestycje w miastach, które może sprzedawać prywatnym inwestorom pod budowę osiedli lub działalność gospodarczą. English Partnership jest także liderem programu partnerskiego szeregu organizacji działających w sferze rewitalizacji terenów pozyskanych po dawnych kopalniach węgla. Tereny te poddane rekultywacji przekształcane są w tereny inwestycyjne. Od 1997 r., gdy powstał ten program (National Coalfields Programme), doprowadzono do inwestycji na ok. 2000 ha, pozostało do zrewitalizowania kolejne 4500 ha.

British Urban Regeneration Assocciation (jej odpowiednikiem w Polsce jest Forum Rewitalizacji) zrzesza firmy i osoby prywatne zainteresowane rewitalizacją. Prowadzi wymianę doświadczeń, badania, szkolenia, konferencje. Wzrost znaczenia rewitalizacji doprowadził do stworzenia szeregu wydawnictw zajmujących się rewitalizacją, portalu internetowego, a także bazy danych o wolnych nieruchomościach przeznaczonych do sprzedaży przez instytucje publiczne.

Poza instytucjami i programami na szczeblu krajowym wiele $\mathrm{z}$ nich funkcjonuje na poziomie regionalnym. Jedną $\mathrm{z}$ najważniejszych jest powołana w każdym regionie Regional Development Agency. Agencje te mają tworzyć wizje rozwoju gospodarczego i rewitalizacji w poszczególnych regionach, a finansowane są $\mathrm{z}$ budżetu centralnego w formie grantów. Dysponują one wydzielonym budżetem (przedtem finansowane były przez różne ministerstwa), a ich elastyczna działalność przyczynia się do powstawania nowych miejsc pracy i nowych inwestycji na zdegradowanych terenach. Ich powołanie w roku 1997 świadczy o pewnym przesunięciu akcentów polityki rewitalizacji ze sfery społecznej z powrotem do sfery gospodarczej.

Niezwykle ważnym elementem w procesach rewitalizacji w Anglii są organizacje na poziomie lokalnym. System brytyjski narzuca konieczność tworzenia partnerstwa firm prywatnych, władz publicznych, organizacji mieszkańców oraz

${ }^{44} \mathrm{~W}$ Polsce przykładem takiego działania jest rewitalizacja szpitala w Chojnicach na cele naukowo-kulturalne - jedna $\mathrm{z}$ pierwszych w naszym kraju rewitalizacji współfinansowanych $\mathrm{z}$ funduszy unijnych. 
innych stowarzyszeń i organizacji pozarządowych. W tych partnerstwach najważniejsza rolę odgrywają lokalne władze. Jedną z form takich organizacji są Local Strategic Partnerships, powstałe w kilkudziesięciu najbardziej zdeprywowanych obszarach Anglii, dla których tworzą strategie rozwoju i finansują je, wykorzystując fundusze rządowe. W ramach tzw. funduszu odnowy sąsiedzkiej (Neighbourhood Renewal Fund) muszą one podjąć walkę z deprywacją w sferze rynku pracy i rynku mieszkaniowego, przestępczości oraz edukacji i zdrowia. Jest to warunkiem finansowania ich programów.

Ciekawą działalność prowadzą BID (Business Improvement Districts), powoływane przez przedsiębiorców, którzy sami się opodatkowują w celu poprawy przestrzeni handlowej na swoim terenie, najczęściej finansując nowe formy zieleni, fontanny i różne inne formy małej architektury. Wiele z nich krytykowanych jest m.in. za zbytnie zawłaszczanie przestrzeni publicznej. Na terenie Anglii i Walii jest ich ok. 70, budżet każdej sięga 0,5-1 mln funtów. Funkcjonują także w Kanadzie, USA i oraz w Niemczech, Irlandii, Serbii i Szkocji.

Urban Regeneration Companies są jedną z wielu form organizacji na szczeblu lokalnym, tworzonych przez największe firmy, organizacje społeczne i Agencje Rozwoju Regionalnego. Ich zadaniem jest pozyskanie przedsiębiorstw prywatnych i koordynacja przedsięwzięć inwestycyjnych współfinansowanych przez sektor publiczny. Sa finansowane w równym stopniu przez agencje rozwoju regionalnego, narodową English Partnership i władze lokalne. Kompanie te nie dysponują własnym budżetem na rewitalizację, która jest finansowana przez firmy prywatne przy wsparciu władz lokalnych.

Nieco odmienny charakter miały w latach osiemdziesiątych i dziewięćdziesiątych Urban Development Corporations, których zadaniem było wykupywanie i przygotowanie terenów dla rewitalizacji. Aktualnie jest ich tylko pięć, w tym jedno zajmuje się rewitalizacją związaną z Igrzyskami Olimpijskimi 2012 w Londynie.

Przykładem programu nastawionego na rozwiązywanie nabrzmiałych problemów społecznych jest New Deal for Communities, rządowy program finansujący $\mathrm{w}$ formie grantów partnerstwa tworzone przez władze lokalne z przedstawicielami mieszkańców ok. 40 najbardziej zdeprywowanych społecznie obszarów Anglii. Ich działania skupiają się na niwelowaniu różnic, jakie dzielą rewitalizowane obszary od średnich krajowych w sferze: bezrobocia, edukacji, przestępczości, jakości życia.

Jednocześnie funkcjonuje od 2005 r. Program Lokalnego Rozwoju Przedsiębiorstw (Local Area Business Growth Incentive), dzięki któremu władze lokalne zatrzymują część kwot z przyrostu podatków od miejscowych firm, które mogą przeznaczyć na dowolny cel wspierający rozwój gospodarczy.

Władzom lokalnym przysługuje też prawo wykupywania terenów od prywatnych właścicieli pod przymusem, np. w przypadku żądania ceny znacznie wyższej od rynkowej. Procedury odwoławcze zabezpieczają interes prywatny, 
cały proces może jednak trwać nawet kilka lat. Ciekawym rozwiązaniem jest obniżanie rekompensaty za spadek wartości spornej nieruchomości w wyniku zaniedbań lub celowego działania właściciela w trakcie tych procedur (w Polsce mamy wiele przykładów celowego niszczenia, podpaleń i umyślnego doprowadzania do ruiny „niewygodnych” dla dewelopera zabytkowych obiektów).

Finansowanie inwestycji rewitalizacyjnych jest najczęściej realizowane w formie partnerstwa publiczno-prywatnego. Lącznie w ciagu ostatnich 40 lat wydano na te cele ok. 100 mld funtów, z czego większość stanowią fundusze prywatne, uzyskiwane głównie z kredytów. Środki publiczne przeznaczane są zazwyczaj na uporządkowanie nieużytkowanych nieruchomości w pierwszej fazie rewitalizacji, natomiast środki prywatne na realizację nowych obiektów komercyjnych. Władze lokalne mogą uzyskać środki na początkowe fazy rewitalizacji z grantów rządowych, które mogą pokryć do $75 \%$ kosztów własnych nakładów.

Ważnym miernikiem oceny projektów rewitalizacyjnych jest tzw. wskaźnik lewarowania, czyli stosunek wydatków publicznych do wartości inwestycji podjętych przez sektor prywatny. Na przykład finansowany przez English Partnership Narodowy Program Węglowy (National Coalfields Programme), którego zadaniem jest rewitalizacja terenów po zlikwidowanych kopalniach węgla kamiennego, przeznaczył od 1997 r. na ten cel 379 mln funtów, co spowodowało kolejne inwestycje sektora prywatnego w wysokości 665 mln funtów.

Jednym ze źródeł finansowania jest Heritage Lottery Fund uzyskujący środki z gier losowych. Fundusz ten przyznaje granty w różnej wysokości przeznaczane na remonty i modernizacje starych, historycznych czesści miast w celu poprawy jakości życia mieszkańców i wzrostu atrakcyjności turystycznej dzielnic zabytkowych. Władze lokalne organizują czasem rozmaite masowe imprezy z udziałem polityków, na które sprzedawane są bilety, z których dochód przeznaczany jest również na rewitalizację.

Ważnym elementem przy obiektywnym doborze obszarów przeznaczonych do rewitalizacji na podstawie wielu kryteriów jest bardzo wysoki poziom statystyki, zdezagregowanej do niewielkich tzw. obszarów sąsiedzkich. Dzięki temu można porównywać ze sobą obszary najbardziej zaniedbane w miastach i sterować ich poprawą. Różnorodne wskaźniki notowane dla niewielkich obszarów miejskich pozwalają też na obserwację i ewentualną zmianę polityki rewitalizacji w trakcie jej realizacji.

Stosowany jest dla powyższych celów indeks wielokrotnej deprywacji, składający się z 7 grup wskaźników (dochody mieszkańców, zatrudnienie, zdrowie, edukacja, bariery dostępu do usług i mieszkań, przestępczość i środowisko życia). Łącznie branych jest pod uwage 37 zmiennych, w tym m.in.: odległość do lekarza, szkoły podstawowej, supermarketu, poczty, liczba mieszkań nadmiernie zagęszczonych, wskaźniki absencji w szkołach, odsetek osób powyżej 16 lat, które już się nie kształcą, statystyki dotyczące objawów depresji psychicznej. 
Ważną częścią procesu rewitalizacji jest jego monitorowanie i ocena. Stosowane są porównania powyższych mierników, dzięki czemu można porównać osiagnięte rezultaty z planowanymi efektami. Obok tego porównywane są dane odnoszące się do przebiegu procesu rewitalizacji. Należą do nich np. liczba nowych miejsc pracy, liczba porad dla firm, miejsc szkoleniowych, powierzchnia zregenerowanej działki, spadek liczby osób o najniższych dochodach, poprawa wskaźników edukacyjnych, liczba zmodernizowanych mieszkań, powierzchnia odnowionej przestrzeni publicznej, parków, wzrost cen nieruchomości. W sferze społecznej, z natury trudniejszej do zmierzenia stosuje się także różne wskaźniki, np.: spadek liczby mieszkańców otrzymujących zasiłki, liczba grantów udzielonych lokalnym grupom działania, różnorodne wskaźniki spadku przestępczości, propagowanie ryzyka związanego z narkotykami i alkoholem, a nawet zasad zdrowego żywienia ${ }^{45}$. Wszystkie te mierniki stosuje się $\mathrm{w}$ odniesieniu do wydatkowanej na rewitalizację kwoty.

Skutki procesów rewitalizacji wywołują oczywiście dyskusje. Jednym z nich jest np. gentryfikacja (ekonomiczna i społeczna). W sensie ekonomicznym, pomimo wielkiego sukcesu osiągniętego przy rewitalizacji doków londyńskich, wprowadzenie tam najwyższej klasy usług, biurowców, prestiżowych hoteli, luksusowych apartamentów i całkowitej odmiany tej zaniedbanej części miasta, rewitalizacja ta zaczęła być poddawana krytyce ze względu na całkowite niemal pominięcie potrzeb mieszkającej tam przedtem ludności (wynikało to z braku konsultacji społecznych) ${ }^{46}$. Przemiany społeczne wynikające z wielkiego rozmachu inwestycyjnego i bardzo nowoczesnej zabudowy objawiły się napływem na te tereny ludności młodszej, prężnej, dobrze wykształconej i zarabiającej, która znacznie przyczyniła się do ich ożywienia. Jednak nadmierna koncentracja ludzi zamożnych wypchnęła na margines dotychczasowych mieszkańców, których nie stać na dalsze zamieszkiwanie w tak zrewitalizowanej części miasta i która niemal nie korzysta $\mathrm{z}$ nagromadzonych tam usług wysokiego rzędu. Obserwacje, poczynione $\mathrm{w}$ wielu miastach $\mathrm{w}$ ten sposób zrewitalizowanych, wskazują na bardzo ograniczony udział mieszkańców w programowaniu procesów odnowy. Ten udział jest często niski tam, gdzie generalnie lokalna społeczność jest słabo zaangażowana w sprawy lokalne, co objawia się np. niską frekwencją wyborczą. Z drugiej strony najlepsze rezultaty osiaga się przez współpracę władz lokalnych z mieszkańcami, która rozpoczyna się od najwcześniejszych faz przygotowań do rewitalizacji.

Samo odnowienie substancji mieszkaniowej, bez przemian społecznych i zasilenia podupadłej dzielnicy nowymi mieszkańcami o wyższych dochodach,

${ }^{45} \mathrm{~W}$ sferze przestępczości używane są m.in. liczba włamań do mieszkań, kradzieży samochodów, napadów. Są one częścią składową tzw. syntetycznego wskaźnika witalności. (G. Micek, Monitoring i ocena procesów rewitalizacji, [w:] R. Guzik (red.), Rewitalizacja miast..., s. 74).

${ }^{46}$ Peter Hall - światowej sławy urbanista i koordynator przebudowy Docklands otrzymał z rąk królowej brytyjskiej tytuł szlachecki i odtąd tytułowany jest Sir Peter Hall. 
powoduje nawrót zjawiska deprywacji. $\mathrm{W}$ ostatnich latach formułowane są ogólne zalecenia, aby nie ograniczać się do fizycznej przebudowy i przyciagania na dany teren zamożniejszych mieszkańców, ale dążyć także do poprawy warunków życia dotychczasowych mieszkańców i ograniczać nierówności społeczne oraz zapewnić ekonomiczne podstawy funkcjonowania rewitalizowanego obszaru.

Bazę dla wzrostu ekonomicznego można uzyskać poprzez stworzenie wielofunkcyjnej struktury danego terenu. Jedną $\mathrm{z}$ najważniejszych jest funkcja handlowa, uzupełniana przez budowę biurowców, na niektórych terenach tworzone były specjalne strefy ekonomiczne (podobnie jak w Polsce), a także parki nauki, parki technologiczne itp. Dobrym uzupełnieniem tych funkcji było powstawanie nowych terenów zielonych - parków, stref rekreacji i sportu.

Zaobserwowano m.in., że samo podniesienie poziomu wykształcenia i kwalifikacji mieszkańców powodowało wzrost ich aspiracji i dochodów, a w konsekwencji przenoszenie się do lepszych dzielnic. Tracono w ten sposób rdzennych mieszkańców danego obszaru o wyższym statusie społecznym. Wniosek nasuwa się sam: skuteczna rewitalizacja powinna polegać na dążeniu do rozwoju zrównoważonego i bacznym obserwowaniu procesu przemian, co umożliwia wczesną eliminację zmian niepożądanych.

Doświadczenia brytyjskie świadczą także o tym, że najskuteczniej realizowane działania rewitalizacyjne powinny polegać na partnerskiej współpracy. Konieczność takiego podejścia wynika $\mathrm{z}$ mnogości przyczyn powstawania zjawisk kryzysowych, a więc ich przezwyciężenie możliwe jest jedynie przez połączenie wysiłków i dążeń wielu różnych partnerów - władz lokalnych, mieszkańców, przedsiębiorców, deweloperów, organizacji pozarządowych. Upatruje się w takich związkach partnerskich większej skuteczności przez osiagganie efektu synergii, m.in. dzięki zaangażowaniu mieszkańców do działań rewitalizacyjny $\mathrm{ch}^{47}$.

${ }^{47}$ Przykład takiego efektu zanotowano podczas badania (w ramach programu RESTATE) cząstkowej rewitalizacji na warszawskim Wrzecionie. Gmina, w uzgodnieniu z mieszkańcami tego niezbyt zamożnego osiedla $\mathrm{z}$ lat 60 ., sfinansowała pewne elementy małej architektury na osiedlu, w tym plac zabaw dla dzieci i piaskownice. Entuzjazm wielu mieszkańców spowodował, że część z nich dołożyła na ten cel własne pieniądze i zaczęła strzec tych nowych obiektów przed lokalnymi wandalami. 